\title{
SYNTHESIS OF CYCLEN BODIPY DYAD AND ITS METAL COMPLEXES: EVALUATION OF ANION RECOGNITION FEATURES
}

Fatih ALGI*, Department of Biotechnology and Molecular Biology \& ASUBTAM Memduh Bilmez BioNano Technology Laboratory/Faculty of Science and Arts, Aksaray University/TR-68100, Aksaray, Turkey, falgi@aksaray.edu.tr

$$
\text { (iD) https://orcid.org/0000-0001-9376-1770) }
$$

Serkan KARAKAYA, Department of Chemistry, Laboratory of Organic Materials/Faculty of Science and Arts, Çanakkale Onsekiz Mart University/TR-17100, Çanakkale, Turkey, skarakaya@comu.edu.tr

(iD https://orcid.org/0000-0002-6401-3295)

Received: 13.01.2019, Accepted: 05.04.2019

*Corresponding author

Research Article DOI: $10.22531 /$ muglajsci.512383

\section{Abstract}

In this study, a new compound, viz. 4,4-Difluoro-8-(1,4,7,10-tetraazacyclododecane)methyl-1,3,5,7-tetramethyl-2,6-diethyl4-bora-3a,4a-diaza-s-indacene (1), and its metal complexes (1-Zn,1-Cu,and1-Ni) are synthesized and spectroscopically characterized (UV-Vis, luminescence-fluorescence, NMR,FTIR, and MS). Anion sensing properties of compound 1 and its metal complexes (1-Zn, 1-Ni and 1-Cu) are tested in the presence of various anionic species in acetonitrile media. Fluorescence measurements indicated that, 1-Ni and 1-Cu do not have any selectivity towards various anions except weak interactions. On the other hand $\mathbf{1 - Z n}$ shows good response and selectivity toward acetate ion based on fluorescence enhancement. In addition, JOB studies demonstrate that the interaction between 1-Zn and acetate ion were with a ratio of 1:2 and limit of detection (LOD) of 1-Zn was calculated as $4.76 \times 10^{-6} \mathrm{M}$ for acetate ion detection. Moreover, 1-Znprovides a certain change in color in the presence of acetate. The results demonstrate that 1-Zn can be utilized for fluorogenic and naked eye detection of acetate anion.

Keywords: BODIPY, Cyclen, Acetate Ion, Zinc(II), Fluorescence

\section{CYCLEN BODIPY ÇIFTINIIN VE BUNLARIN METAL KOMPLEKSLERINIIN SENTEZİ: ANYON TANIMA ÖZELLİKLERINIIN DEĞERLENDİRILMESİ}

Özet

Bu çalışmada, yeni bir bileşik, 4,4-Difloro-8-(1,4,7,10-tetraazasiklododekan)metil-1,3,5,7-tetrametil-2,6-dietil-4-bora-3a,4adiaza-s-indasen (1) ve bu bileşiğin metal kompleksleri (1-Zn, 1-Ni ve 1-Cu) tasarlanmış, sentezlenmiş ve spektroskopik (UVVis, luminesans-floresans, FTIR, NMR ve Kütle Spektroskopisi) olarak karakterize edilmiştir. Bileşik 1'in ve metal komplekslerinin (1-Zn, 1-Ni ve 1-Cu) anyon algılama özellikleri, asetonitril ortamında çeşitli anyonik türlerin varlığında test edilmiştir. Floresans ölçümleri, 1-Ni ve 1-Cu'ın bu anyonik türlere karşı zayıf etkileşimlerinin haricinde bir seçiciliğe sahip olmadığını göstermiştir. Diğer taraftan 1-Zn, floresans artışına bağlı olarak asetat anyonuna karşı iyi bir yanıt ve seçicilik göstermektedir. Buna ek olarak, JOB verileri, 1-Zn ile asetat iyonu arasındaki etkileşimin 1:2 oranında olduğunu göstermekte olup asetat iyonunun algılanması için tayin sınırı (LOD) $4.76 \times 10^{-6} \mathrm{M}$ olarak hesaplanmıştır. Ayrıca1-Zn, asetat varlığında kesin bir renk değişimine olanak sağlamaktadır. Sonuçlar, 1-Zn'nin, asetat anyonunun florojenik ve çıplak gözle algılanması için kullanılabileceğini göstermektedir.

Anahtar Kelimeler: BODIPY, Cyclen, Asetat İyonu, Çinko(II), Floresans

Cite

Algi, F., Karakaya, S. (2019). "Synthesis of cyclen bodipy dyad and its metal complexes: evaluation of anion recognition features", Mugla Journal of Science and Technology, 5(1), 69-99.

\section{Introduction}

Selective anion sensing is an important topic in supramolecular chemistry due to the critical roles of anions in various biological and environmental processes [1-3]. Among anionic species, acetate anion $\left(\mathrm{AcO}^{-}\right)$plays significant roles in enzyme activity, hormones transporting, synthesis of proteins and regulation of DNA expression [4]. Also, $\mathrm{AcO}^{-}$is a remarkable one because of its function in blood washing and blood vessel softening [5]. However, high concentrations of $\mathrm{AcO}^{-}$in human body can interact with $\mathrm{Ca}^{2+}$ cation to form calcium acetate which can cause urinary calculi disease [5]. Furthermore, quantity of 
$\mathrm{AcO}^{-}$in marine sediments gives information about sedimentation rate in organic decomposition [1]. Therefore, the detection of $\mathrm{AcO}^{-}$is highly important. Fluorescent probes offer one of the best methods for the detection of $\mathrm{AcO}^{-}$ion. Thus, many studies have been performed for synthesis and designing of fluorescent $\mathrm{AcO}^{-}$probes in recent years [1, 4-17].

In anion recognition chemistry, noncovalent interactions between a receptor and an anion can occur by three ways: i) hydrogen bonding, ii) electrostatic interaction or iii) coordination with metal cations [1]. Coordination between metal cations and anions is an efficient way in anion sensing. In addition, other parameters like molecule rigidity, the distance and connection of a binding site between anion and metal ion center are important factors to increase the analyte binding response of a luminescent probe [18]. On the other hand, azole species based on macrocyclic ligand have been generally used for their effect on numerous biological activities such as anticancer, antiviral, antitubercular etc [19]. Among those macrocyclic species,1, 4, 7, 10-tetraazacyclododecane (cyclen) and its species are defined as good chelators, which can coordinate strongly to various cations. $\mathrm{Zn(II)} \mathrm{complexes}$ of cyclen derivatives have been used for luminescent sensing of biologically important anions such as phosphate species $[18,20-24]$, thymine/thymidine nucleotides [25-29] and be used as hydrolytic DNA cleavage promoter [30].

One of the most popular fluorophore family is 4,4-difluoro-4-bora-3a,4a-diaza-s-indacene (BODIPY) derivatives [31-41]. BODIPYs are versatile fluorescent dyes and widely used in designing donor-acceptor systems, artificial light harvesters, fluorescent sensors, laser dyes and light emitting devices because of their excellent properties: sharp emission bands and high absorption capacities in the visible region, efficient light-harvesting capability, high fluorescence quantum yields, facility of modification at all positions of the main structure, long excited state lifetimes and remarkable photo-stability and good solubility in organic solvents [42].

In this paper, the design and synthesis of a novel cyclen BODIPY dyad $\mathbf{1}$ and its metal complexes (1-M: 1Zn, 1-Cu and 1-Ni) (Chart 1) have been reported.
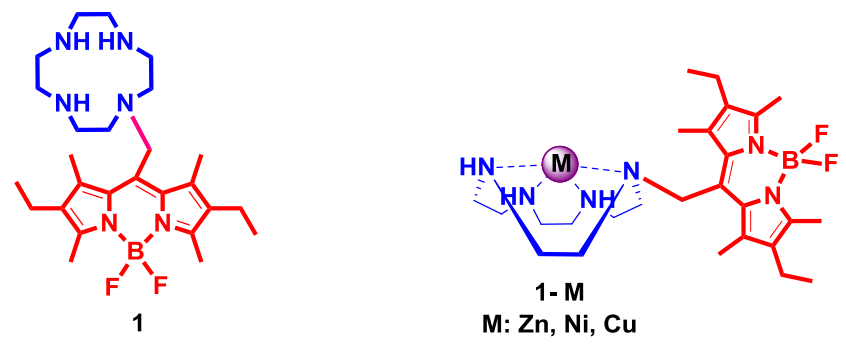

Furthermore, evaluation of anion recognition features of cyclen BODIPY dyads were also described. It was found that $\mathbf{1 - Z n}$ can be used as a dual channel acetate probe, which enables fluorogenic and naked-eye detection of this anion (Scheme 1). It should be noted that there has been a limited number of reports concerning the design and synthesis of cyclen BODIPY dyads, which can be used as fluorescent probes [43-46]. As far as we know these compounds represent one of the rare examples of cyclen BODIPY dyads.

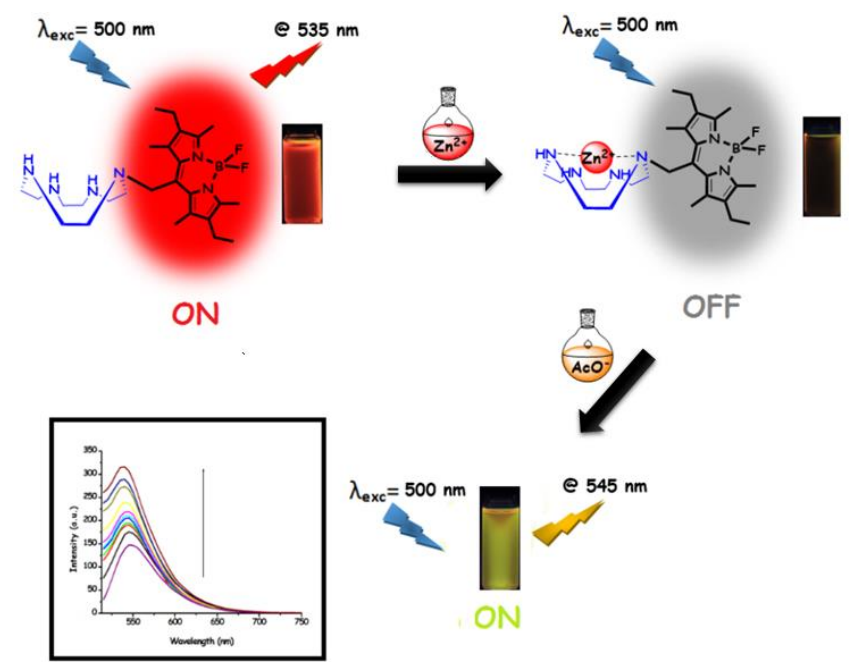

Scheme 1. Complexation of 1 with $\mathrm{Zn}(\mathrm{II})$ ion and off-on process.

\section{Experimental Section}

All chemicals were supplied from Merck or Sigma Aldrich company. FTIR spectrums were recorded usinga Perkin Elmer Spectrum 100 model FTIR with an ATR (attenuated total reflectance). ${ }^{1} \mathrm{H}$ and ${ }^{13} \mathrm{C} \quad \mathrm{NMR}$ spectrums were recorded on a Bruker DPX-400 or Ultrashield $300 \quad$ NMR Spectrometers. Mass measurements were recorded using a Bruker microflex LT MALDI TOF MS and Bruker microflex TOF-ESI/MS. UV-vis and fluorescence spectrums were recorded using a Varian Cary 50 and a Varian Cary Eclipse spectrophotometers, respectively. Melting points were measured with a Schorrp MPM-H2 model device. Column chromatography was realized using silica gel (60-200 mesh) from Merck Company. TLC was performed on analytical aluminum plates (Merck 0.2 $\mathrm{mm}$ silica gel 60 F254). Compounds 2 and 3 were synthesized by previously published works $[47,48]$. The tert-butyl ammonium salts were used to prepare the anion solutions.

2.1. Synthesis of 4,4-Difluoro-8-(1,4,7,10tetraazacyclo-dodecane) methyl-1,3,5,7-tetramethyl -2,6-diethyl-4-bora-3a,4a-diaza-s-indacene (1)

Compound 3 (93.6 mg, $0.211 \mathrm{mmol}$ ) in dry $\mathrm{CH}_{2} \mathrm{Cl}_{2}(10$ $\mathrm{mL}$ ) was added dropwise to a solution of compound 2 (145.2 $\mathrm{mg}, 0.843 \mathrm{mmol}$ ) and dry triethylamine (36 $\mu \mathrm{L}$, $0.253 \mathrm{mmol})$ in dry $\mathrm{CH}_{2} \mathrm{Cl}_{2}(15 \mathrm{~mL})$ under nitrogen. The reaction mixture was heated under reflux until TLC analysis indicated that all the starting material had been 
consumed. The mixture was filtered, then solvent was removed under reduced pressure. The residue was subjected to silica gel column chromatography by eluting with $\mathrm{CH}_{2} \mathrm{Cl}_{2} \rightarrow$ Toluene: Hexane 3:1 $\rightarrow \mathrm{Et}_{2} \mathrm{O}$ : $\mathrm{MeOH} \mathrm{1:1} \mathrm{to} \mathrm{give} 1$ as red solid: $70 \mathrm{mg}, 68 \%$; mp 145$148{ }^{\circ} \mathrm{C} .{ }^{1} \mathrm{H}$ NMR (400 MHz, $\left.\mathrm{CDCl}_{3}\right): \delta / \mathrm{ppm} 4.13(\mathrm{~s}, 2 \mathrm{H})$, $2.98(\mathrm{~m}, 8 \mathrm{H}), 2.76(\mathrm{~m}, 8 \mathrm{H}), 2.52(\mathrm{~s}, 6 \mathrm{H}), 2.42(\mathrm{~m}, 10 \mathrm{H})$, $1.06(\mathrm{t}, \mathrm{J}=7.54 \mathrm{~Hz}, 6 \mathrm{H}) ;{ }^{13} \mathrm{C} \mathrm{NMR}\left(100 \mathrm{MHz}, \mathrm{CDCl}_{3}\right)$ : $\delta /$ ppm 154.29, 136.72, 135.96, 133.72, 132.47, 73.38, 51.30, 49.01, 47.95, 45.78, 17.20, 14.79, 13.87, 12.65; FTIR $\left(\mathrm{cm}^{-1}\right): 3278,2694,2930,2870,1666,1602,1544$ $1475,1404,1373,1358,1264,1229,1190,1405,976$, 750, 723; MALDI-TOF-MS (Matrix:2,5-Dihydroxybenzoic acid) $m / z$ calcd for $\mathrm{C}_{26} \mathrm{H}_{43} \mathrm{BF}_{2} \mathrm{~N}_{6}, 488.36 \mathrm{~g} / \mathrm{mol}$, found $[\mathrm{M}]^{+}: 489.01 \mathrm{~g} / \mathrm{mol}$; Anal Calcd for $\mathrm{C}_{26} \mathrm{H}_{43} \mathrm{BF}_{2} \mathrm{~N}_{6}$ : C, 63.93; H, 8.87; N, 17.20; Found: C, 63.75; H, 8.57; N, 17.50.

\subsection{The Synthesis Procedure of Metal Complexes (1-Zn, 1-Ni and 1-Cu)}

$\mathrm{M}\left(\mathrm{ClO}_{4}\right)_{2} \cdot 6 \mathrm{H}_{2} \mathrm{O}(0.2346 \mathrm{mmol})$ solution of in $10 \mathrm{~mL}$ absolute methanol was slowly added to a magnetically stirred solution of compound 1 (114.6 mg, 0.2346 mmol) in $20 \mathrm{~mL}$ absolute methanol. The mixture was heated under reflux until TLC analysis confirmed that the starting material was consumed. Solvent was evaporated and a black solid was obtained. It was dissolved in a minimum amount of THF and precipitated out by diethylether or petroleum ether.

1-Zn: 120 mg, 93\% yield; mp 135-137 ${ }^{\circ} \mathrm{C} .{ }^{1} \mathrm{H}$ NMR (400 $\left.\mathrm{MHz}, \mathrm{CD}_{3} \mathrm{CNand} \mathrm{CDCl}_{3}\right): \delta / \mathrm{ppm} 3.84(\mathrm{~s}, 2 \mathrm{H}), 2.99(\mathrm{~m}$, $8 \mathrm{H}), 2.78(\mathrm{~m}, 8 \mathrm{H}), 2.39(\mathrm{~m}, 16 \mathrm{H}), 1.08(\mathrm{t}, \mathrm{J}=7.45 \mathrm{~Hz}, 6 \mathrm{H})$; FTIR $\left(\mathrm{cm}^{-1}\right): 3504,3457,2969,2933,2875,1630,1568$, 1444, 1323, 1282, 1056, 957, 713;LC-MS $\mathrm{m} /$ zcalcd for $\mathrm{C}_{26} \mathrm{H}_{43} \mathrm{BF}_{2} \mathrm{~N}_{6} \mathrm{Zn}: 552.29 \mathrm{~g} / \mathrm{mol}$, found $\left[\mathrm{M}+\mathrm{CH}_{3} \mathrm{OH}\right]^{+}$: $583.10 \mathrm{~g} / \mathrm{mol}$; MALDI-TOF-MS (no matrix was used) $\mathrm{m} /$ zcalcd for $\mathrm{C}_{26} \mathrm{H}_{43} \mathrm{BF}_{2} \mathrm{~N}_{6} \mathrm{Zn}$ : $552.29 \mathrm{~g} / \mathrm{mol}$, found $[\mathrm{M}+\mathrm{H}+\mathrm{Na}]^{+}: \quad 576.77 \mathrm{~g} / \mathrm{mol}$; Anal Calcd for $\mathrm{C}_{26} \mathrm{H}_{43} \mathrm{BF}_{2} \mathrm{~N}_{6} \mathrm{Zn}: \mathrm{C}, 56.38 ; \mathrm{H}, 7.83 ; \mathrm{N}, 15.17$; Found: C, $56.20 ; \mathrm{H}, 7.70 ; \mathrm{N}, 15.30$.

1-Ni: $65 \mathrm{mg}, 41 \%$ yield; mp 126-128 ${ }^{\circ} \mathrm{C}$; FTIR $\left(\mathrm{cm}^{-1}\right)$ : 3424, 3331, 3280, 2967, 2933, 2876, 1641, 1538, 1474, 1444, 1191, 1059, 972, 677; MALDI-TOF-MS (Matrix:1,8,9-Anthracenetriol (Dithranol)) $\mathrm{m} / \mathrm{z}$ calcd for $\mathrm{C}_{26} \mathrm{H}_{43} \mathrm{BF}_{2} \mathrm{~N}_{6} \mathrm{Ni}: 546.30 \mathrm{~g} / \mathrm{mol}$, found $[\mathrm{M}+\mathrm{H}]^{+}$: 547.05 g/mol; Anal Calcd for $\mathrm{C}_{26} \mathrm{H}_{43} \mathrm{BF}_{2} \mathrm{~N}_{6} \mathrm{Ni}$ : C, 57.07; H, 7.92; N, 15.36; Found: C, 57.17; H, 7.70; N, 15.45 .

1-Cu: $105 \mathrm{mg}, 66 \%$ yield; mp 130-133 ${ }^{\circ} \mathrm{C}$; FTIR $\left(\mathrm{cm}^{-1}\right)$ : 3499, 3280, 2969, 2934, 2876, 1595, 1544, 1442, 1376, 1328, 1266, 1190, 1056, 969, 929, 683; MALDI-TOF-MS (Matrix:2,5-Dihydroxybenzoic acid) $\mathrm{m} / \mathrm{z}$ calcd for $\mathrm{C}_{26} \mathrm{H}_{43} \mathrm{BF}_{2} \mathrm{~N}_{6} \mathrm{Cu}: 551.29 \mathrm{~g} / \mathrm{mol}$, found $[\mathrm{M}+\mathrm{H}]^{+}$: 552.16 $\mathrm{g} / \mathrm{mol}$; Anal Calcd for $\mathrm{C}_{26} \mathrm{H}_{43} \mathrm{BF}_{2} \mathrm{~N}_{6} \mathrm{Cu}$ : C, 56.57; $\mathrm{H}, 7.85$; $\mathrm{N}, 15.22$; Found: C, 56.40; H, 7.70; N, 15.45.

\section{Results and Discussions}

Synthetic route for some potential luminescent anion probes (1-Zn, $\mathbf{1 - N i}$ and $\mathbf{1 - C u}$ ) based on compound $\mathbf{1}$ was shown in Scheme 2.
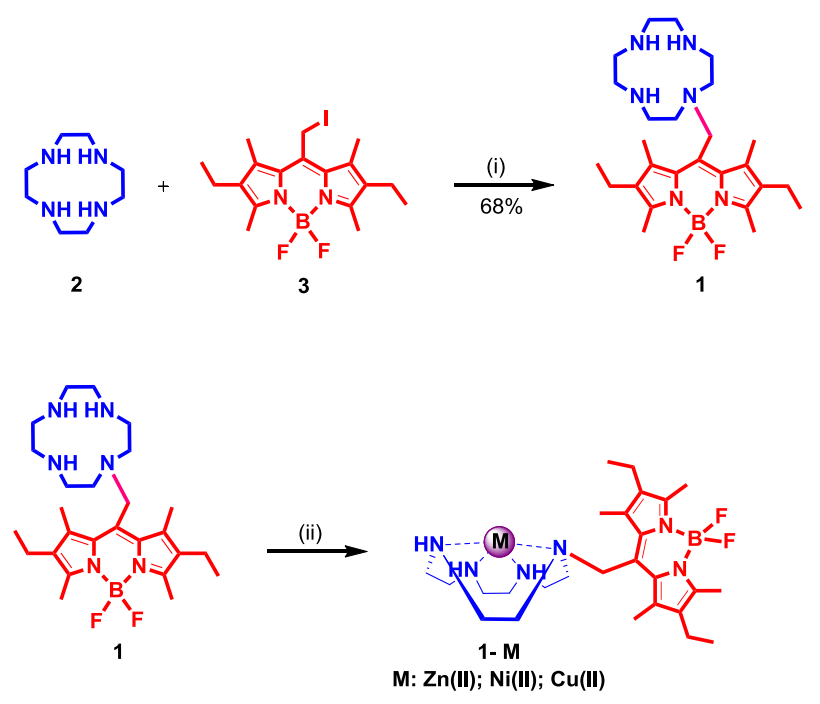

Scheme 2. Reaction conditions: (i) $\mathrm{NEt}_{3}$, dry $\mathrm{CH}_{2} \mathrm{Cl}_{2}$, $40{ }^{\circ} \mathrm{C}$, (ii) $\mathrm{M}\left(\mathrm{ClO}_{4}\right)_{6} \cdot 6 \mathrm{H}_{2} \mathrm{O}, \mathrm{CH}_{3} \mathrm{OH}, 65^{\circ} \mathrm{C}$.

First of all, the compounds $\mathbf{2}$ and $\mathbf{3}$ were synthesized according to well-established procedures $[47,48]$. Then, cyclen (2) and iodomethyl BODIPY (3) were reacted in presence of $\mathrm{NEt}_{3}$ in dry $\mathrm{CH}_{2} \mathrm{Cl}_{2}$ at $40{ }^{\circ} \mathrm{C}$ to obtain compound 1 in 68\% yield as red solid. Finally, cyclenBODIPY metal complexes (1-Zn, 1-Cu and 1-Ni) were acquired by the treatment of $\mathbf{1}$ with perchlorate salts of $\mathrm{Zn}$ (II), Ni (II) and $\mathrm{Cu}$ (II) in refluxing methanol. The compounds were characterized by traditional spectroscopic methods (see Supporting Information for details).

Absorption spectra of target compounds 1, 1-Zn, 1-Ni and 1-Cu were recorded in acetonitrile solution at different concentrations (see Fig. 1a and Fig. S15). The maxima of absorption ( $\left.\lambda_{\mathrm{Abs}}\right)$ and extinction coefficients $(\varepsilon)$ of $\mathbf{1}, \mathbf{1 - Z n}, \mathbf{1 - N i}$ and $\mathbf{1 - C u}(9 \mu \mathrm{M})$ were tabulated in Table 1. Fluorescence properties of the compounds were also examined. Fluorescence spectrum of compound $1(0.04 \mu \mathrm{M})$ exhibited a broad emission band $\left(\lambda_{\mathrm{FL}}\right)$ between $500 \mathrm{~nm}$ and $600 \mathrm{~nm}$ with a maximum at $545 \mathrm{~nm}\left(\lambda_{\text {exc }}=500 \mathrm{~nm}\right)$ (Fig. 1b). 


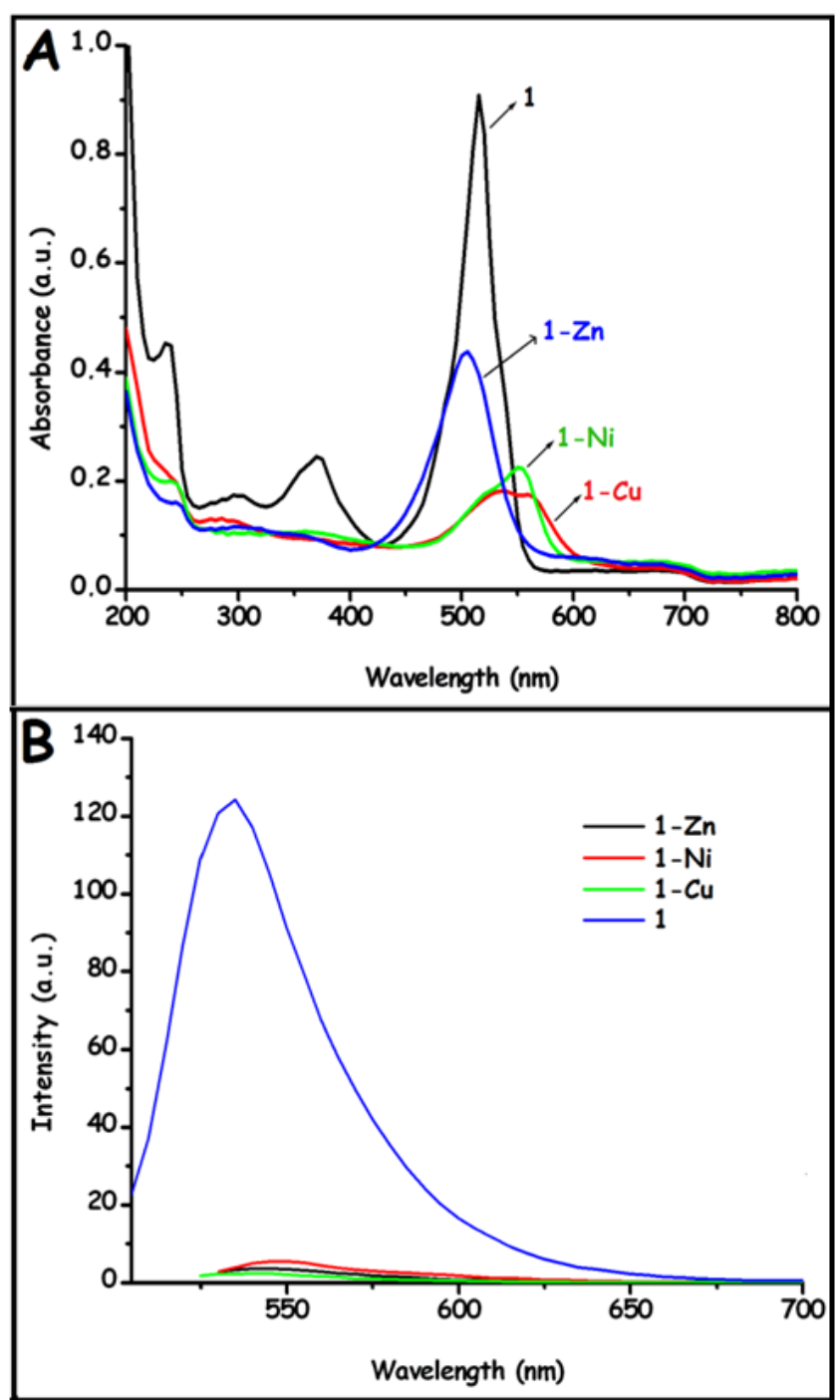

Figure 1. (a) Absorption $(9 \mu \mathrm{M})$, (b) Emission spectra $(0.04 \mu \mathrm{M})$ of 1, 1-Zn, 1-Ni and 1-Cu in $\mathrm{CH}_{3} \mathrm{CN}\left(\lambda_{\mathrm{exc}}=500\right.$ $\mathrm{nm})$.

Table 1. Selected spectroscopic data for $\mathbf{1}, \mathbf{1}-\mathbf{Z n}, \mathbf{1}-\mathbf{N i}$, and 1-Cu.

\begin{tabular}{cccc}
\hline \multirow{2}{*}{ Compound } & \multicolumn{2}{c}{ UV-Vis } & Fluorescence \\
\cline { 2 - 4 } & $\lambda_{\text {Abs }}[\mathrm{nm}]$ & $\varepsilon\left[\mathrm{M}^{-1} \mathrm{~cm}^{-1}\right]$ & $\lambda_{\text {FL }}[\mathrm{nm}]$ \\
\hline $\mathbf{1}$ & 515 & 114150 & 545 \\
$\mathbf{1 - Z n}$ & 505 & 66630 & - \\
$\mathbf{1 - N i}$ & 550 & 41140 & - \\
$\mathbf{1}$ & & 30830, & - \\
\hline
\end{tabular}

On the other hand, it was noted that complexation of compound 1 with metal cations resulted in a complete disappearance of the emission band. The complexation with metal ions might activate the photoinduced electron transfer (PeT) process between BODIPY unit and metal binding site. The activation of PeT process would lead to quenching of the fluorescence, thus a decreased emission is observed. Furthermore, the
HOMO and LUMO energy levels of metallic species of the compound $\mathbf{1}$ activates PET when compared with the metal-free state and the paramagnetic nature of the transition elements, such as $\mathrm{Ni}(\mathrm{II})$ and $\mathrm{Cu}(\mathrm{II})$, would play critical role by providing pathways for nonradiative decay of the excited state.

Anion sensing features of compound $\mathbf{1}$ and metal complexes (1-Zn, $\mathbf{1}-\mathbf{N i}$ and $\mathbf{1 - C u})$ were investigated by spectrophotometric titrations. UV-vis and fluorimetric titrations of compounds 1, 1-Zn, 1-Ni and 1-Cu were carried out with various anions such as $\mathrm{AcO}-\mathrm{F}^{-}, \mathrm{H}_{2} \mathrm{PO}_{4}$; $\mathrm{BF}_{4}, \mathrm{ClO}_{4}, \mathrm{PF}_{6}, \mathrm{I}^{-}, \mathrm{OH}^{-}, \mathrm{Br}^{-}$and $\mathrm{Cl}^{-}$in acetonitrile in order to see the effects of these anions on UV-vis and fluorescence spectra of the metal complexes. It was found that there has been no significant change in the absorption or emission profiles of $\mathbf{1}, \mathbf{1}-\mathbf{N i}$ and $\mathbf{1}-\mathbf{C u}$ during the spectrophotometric titrations. It can be interpreted that 1-Ni and 1-Cu show no sensitivity towards any of these anions. By contrast, UV-Vis spectrophotometric titration experiments indicated that there are dramatic changes in the absorption spectra of 1-Zn upon addition of $\mathrm{AcO}^{-}, \mathrm{OH}^{-}$and $\mathrm{F}^{-}$anions whereas the other anions $\left(\mathrm{H}_{2} \mathrm{PO}_{4}^{-}, \mathrm{BF}_{4}^{-}, \mathrm{ClO}_{4}^{-}, \mathrm{PF}_{6}^{-}, \mathrm{I}^{-}, \mathrm{Br}^{-}\right.$and $\left.\mathrm{Cl}^{-}\right)$ did not cause any significant change (Fig. 2). It was noted that the absorption intensity was decreased upon addition of these anions. The spectral and relative absorption intensity changes were given in Fig. 2. The most significant change was observed for $\mathrm{AcO}$. In addition to that, the absorption band of 1-Zn centered at $505 \mathrm{~nm}$ was slightly shifted upon addition of $\mathrm{F}^{-}$and/or $\mathrm{OH}^{-}$anions (ca. $5 \mathrm{~nm}$ and $10 \mathrm{~nm}$, respectively). It means that $\mathrm{F}^{-}$and $\mathrm{OH}^{-}$induced a blue shift in the absorption maxima along with a concomitant decrease in the absorption band of 1-Zn. However, there was no change at the position of the absorption band $(505 \mathrm{~nm})$ in the case of $\mathrm{AcO}^{-}$when compared with $\mathrm{OH}^{-}$or $\mathrm{F}^{-}$anions (Fig. 2a). 


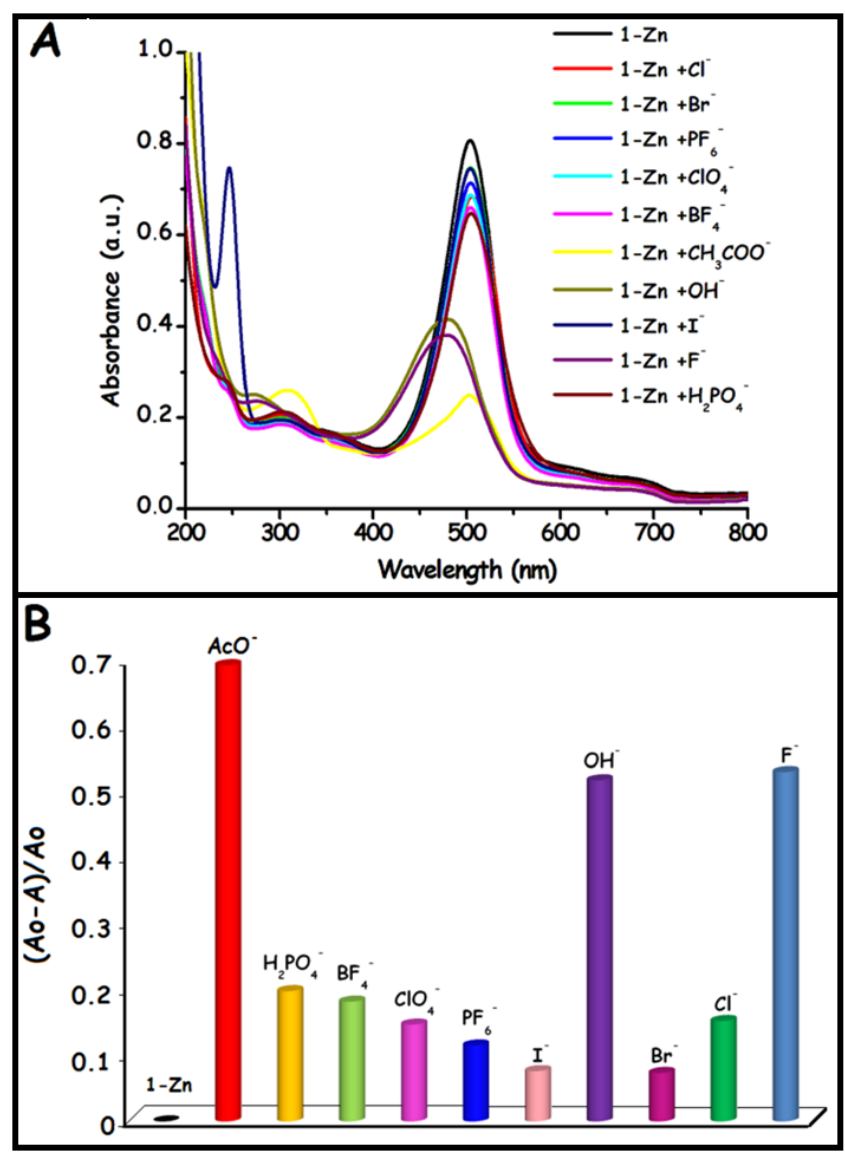

Figure 2. (a) Absorption spectrum and (b) changes in relative absorption intensity of $\mathbf{1 - Z n}(33 \mu \mathrm{M})$ towards various anions (1.0 equiv.): $\mathrm{Cl}^{-}, \mathrm{Br}^{-}, \mathrm{PF}_{6}, \mathrm{ClO}_{4}, \mathrm{BF}_{4}^{-}, \mathrm{I}^{-}$, $\mathrm{H}_{2} \mathrm{PO}_{4}^{-}, \mathrm{OH}-\mathrm{F}^{-}$and $\mathrm{AcO}-$ in $\mathrm{CH}_{3} \mathrm{CN}$.

Further investigations were focused on the concentration-dependency of these changes. Fig. 3 shows the recorded UV-vis spectrum of $\mathbf{1 - Z n}(36 \mu \mathrm{M})$ as a function of $\mathrm{AcO}^{-}$concentration. It is noteworthy that there is a progressive decrease in absorbance at $505 \mathrm{~nm}$ with a concomitant increase at $310 \mathrm{~nm}$.

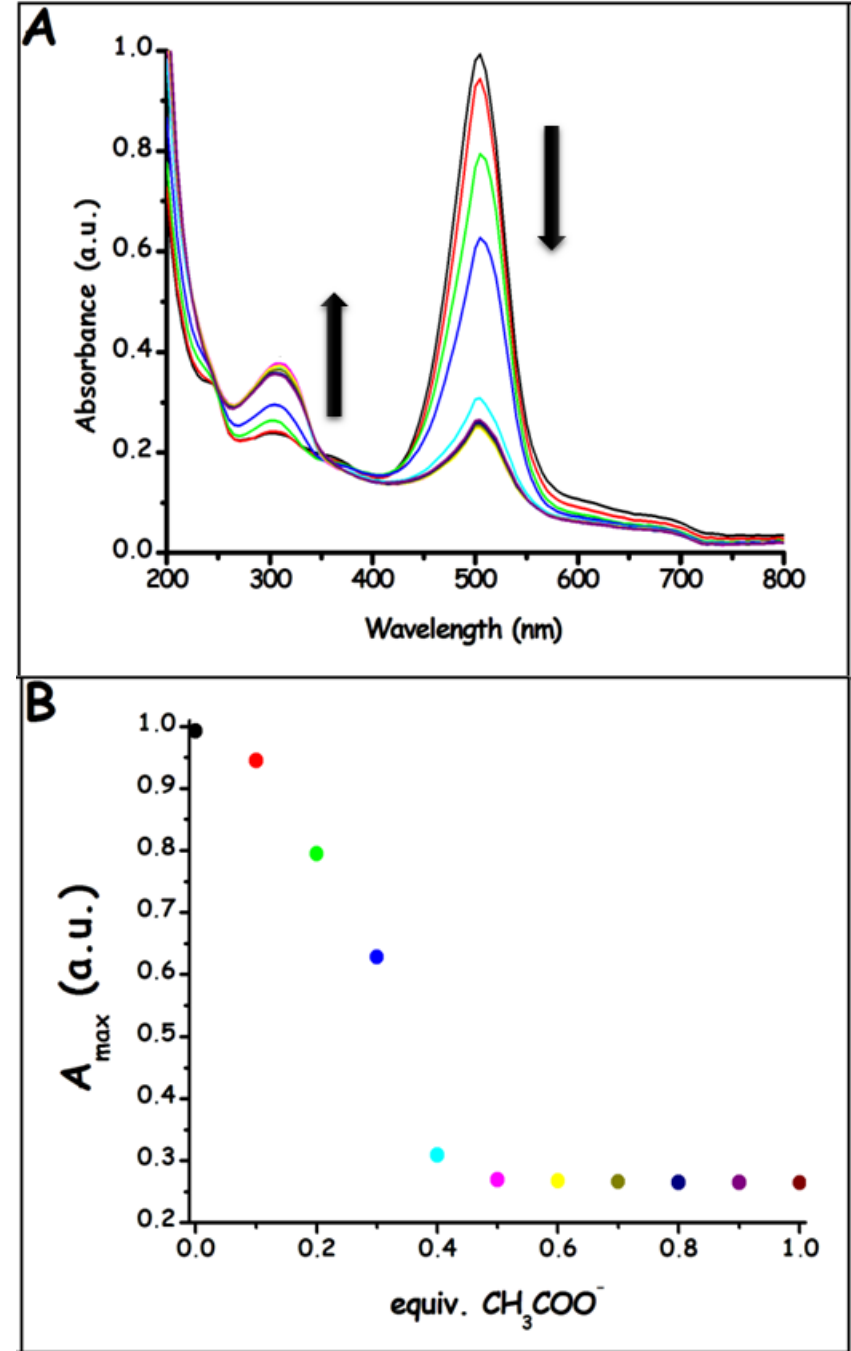

Figure 3. (a) Absorption spectrum of 1-Zn $(36 \mu \mathrm{M})$ toward various amounts $(0,0.1,0.2,0.3,0.4,0.5,0.6,0.7$,

$0.8,0.9$ and 1.0 equiv.) of $\mathrm{AcO}^{-}$in acetonitrile; (b) Absorption changes of $1-\mathrm{Zn}$ with respect to the amount of AcO- $(0,0.1,0.2,0.3,0.4,0.5,0.6,0.7,0.8,0.9$ and 1.0 equiv.).

It indicated that $\mathbf{1 - Z n}$ interacts appreciably with $\mathrm{AcO}$. The effect was maximum in the presence of 0.5 equiv of AcO- and no further change was seen by addition of higher amounts. Similar results were also obtained for $\mathrm{OH}^{-}$and $\mathrm{F}^{-}$anions (Fig. S16 and S17). As the amount of the anion increases, the absorption band centered at $505 \mathrm{~nm}$ decreases with concomitant increase at the absorption band at $300 \mathrm{~nm}$. When all the changes in the absorption spectra of 1- $\mathbf{Z n}$ with $\mathrm{AcO}^{-}, \mathrm{OH}^{-}$and $\mathrm{F}^{-}$anions were compared, it was observed that absorbance diminishes explicitly in the cases of $\mathrm{AcO}^{-}$and $\mathrm{F}^{-}$whereas $\mathrm{OH}^{-}$causes a relatively weak for 0.5 equiv of the anion. In all cases, however, titration curves reach a plateau for 0.5 equiv of the anions. To our delight, the changes in the UV-vis absorption spectra of $\mathbf{1 - Z n}$ were quite enough to induce color changes which were easily detectable by the naked-eye in the daylight. Fig. 4 shows the accompanied colors changes of compounds 1, 1-Zn, 1-Zn-AcO-, 1-Zn- $\mathrm{OH}^{-}$and 1-Zn-F- in acetonitrile solution. As it can be seen clearly, the intensity of colors 
allows the discrimination of these anions from one another to an extent. Note that the color change is a straightforward, cheap and convenient way of visual analysis.

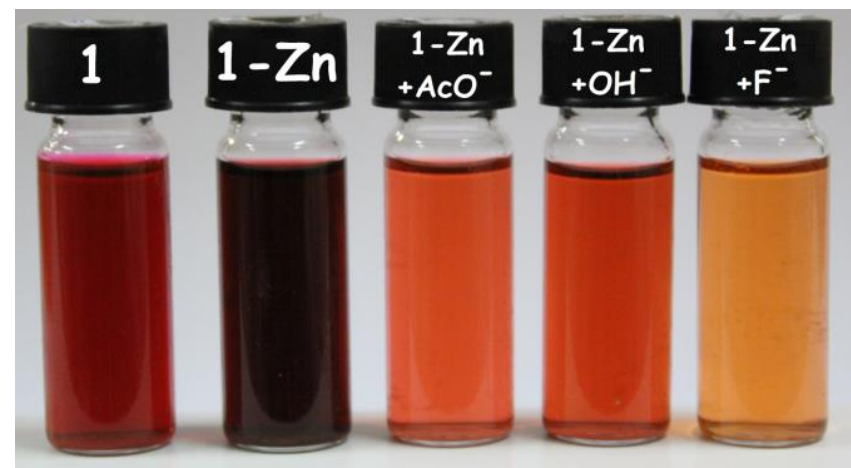

Figure 4. Compounds $1(33 \mu \mathrm{M}), \mathbf{1 - Z n}(33 \mu \mathrm{M}), \mathbf{1 - Z n}-$ AcO- $(36 \mu \mathrm{M}), \mathbf{1 - Z n - 0 H}-(33 \mu \mathrm{M})$ and 1-Zn-F-(33 $\mu \mathrm{M})$ in acetonitrile solution under ambient light (1.0 equiv. of anions).

After the elucidation of UV-vis absorption features of $\mathbf{1 -}$ Zn, fluorescence spectral properties were evaluated. It was found that $\mathrm{Cl}^{-}, \mathrm{Br}^{-}, \mathrm{PF}_{6}^{-}, \mathrm{ClO}_{4}^{-}, \mathrm{BF}_{4}^{-}, \mathrm{I}^{-}$and $\mathrm{H}_{2} \mathrm{PO}_{4}^{-}$ anions did not influence the emission spectrum of $\mathbf{1 - Z n}$ significantly (Fig. 5a). Fortunately, the intensity in emission was increased with a concomitant blue shift (ca $5 \mathrm{~nm}$ ) when $\mathrm{AcO}^{-}$was added to solution. Surprisingly, however, the intensity of $\mathbf{1 - Z n}$ was decreased in the presence of $\mathrm{OH}^{-}$and $\mathrm{F}^{-}$anions. These anions also lead similar blue shift in the emission maxima as in the case of $\mathrm{AcO}^{-}$. Fig. $5 \mathrm{~b}$ shows the relative emission intensity changes of 1-Zn in the presence of all of these anions. It was apparent that $\mathrm{AcO}^{-}$induced the most significant change when compared to others.

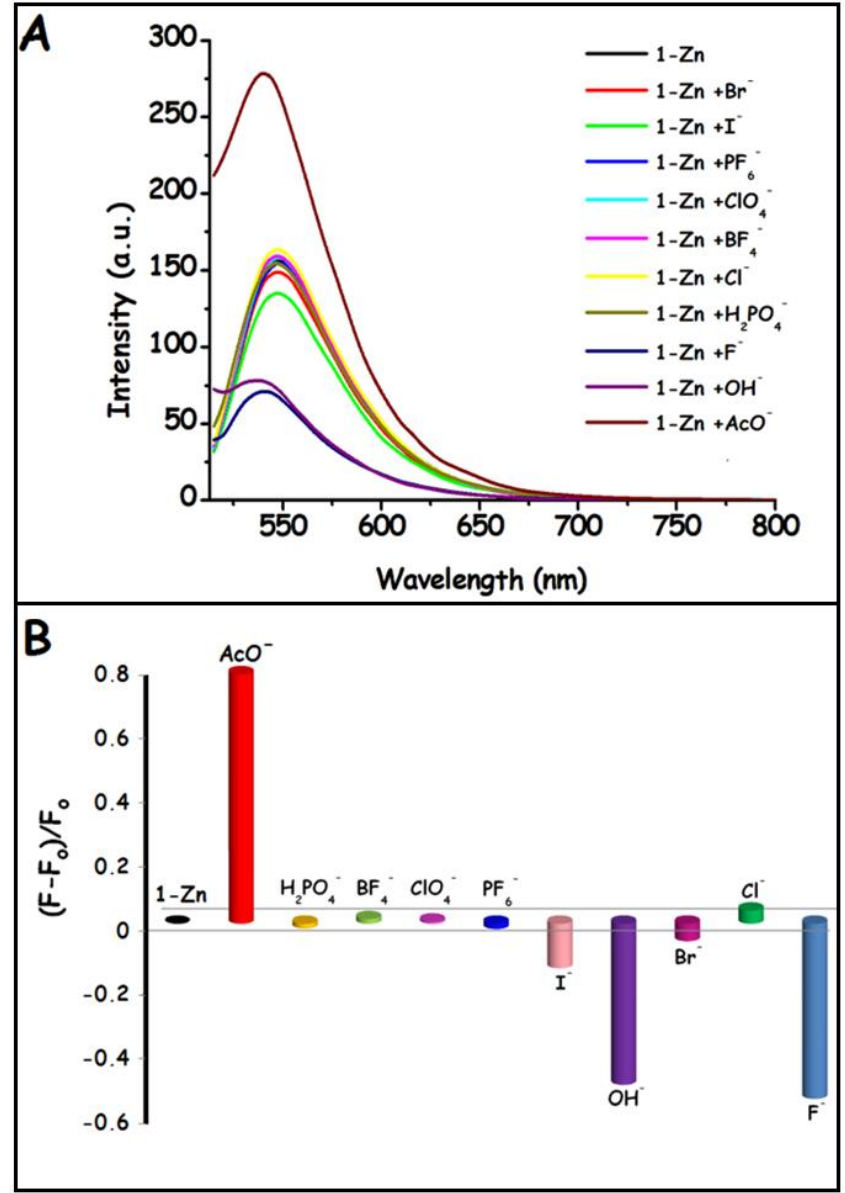

Figure 5. (a) Fluorescence spectra and (b)changes in relative emission intensity of $\mathbf{1 - Z n}(24 \mu \mathrm{M})$ for various anions (1.0 equiv.): $\mathrm{Cl}^{-}, \mathrm{Br}^{-}, \mathrm{PF}_{6}^{-}, \mathrm{ClO}_{4}^{-}, \mathrm{BF}_{4}^{-}, \mathrm{I}^{-}, \mathrm{H}_{2} \mathrm{PO}_{4}^{-}, \mathrm{OH}^{-}$, $\mathrm{F}^{-}$and $\mathrm{AcO}^{-}$in $\mathrm{CH}_{3} \mathrm{CN}\left(\lambda_{\text {exc }}=500 \mathrm{~nm}\right)$.

Similarly, concentration dependency of the fluorescence spectral changes was also monitored. To this purpose, fluorescence spectra of $\mathbf{1 - Z n}$ were recorded as a function of $\mathrm{AcO}^{-}$concentration (Fig 6). It was seen that there was a progressive enhancement in the emission intensity as the amount of the anion was increased. A concomitant blue shift was also observed, which pointed out that $\mathbf{1 - Z n}$ interacts appreciably with AcOThere was a one-fold increase in the emission intensity for 1.0 equiv of $\mathrm{AcO}^{-}$. 


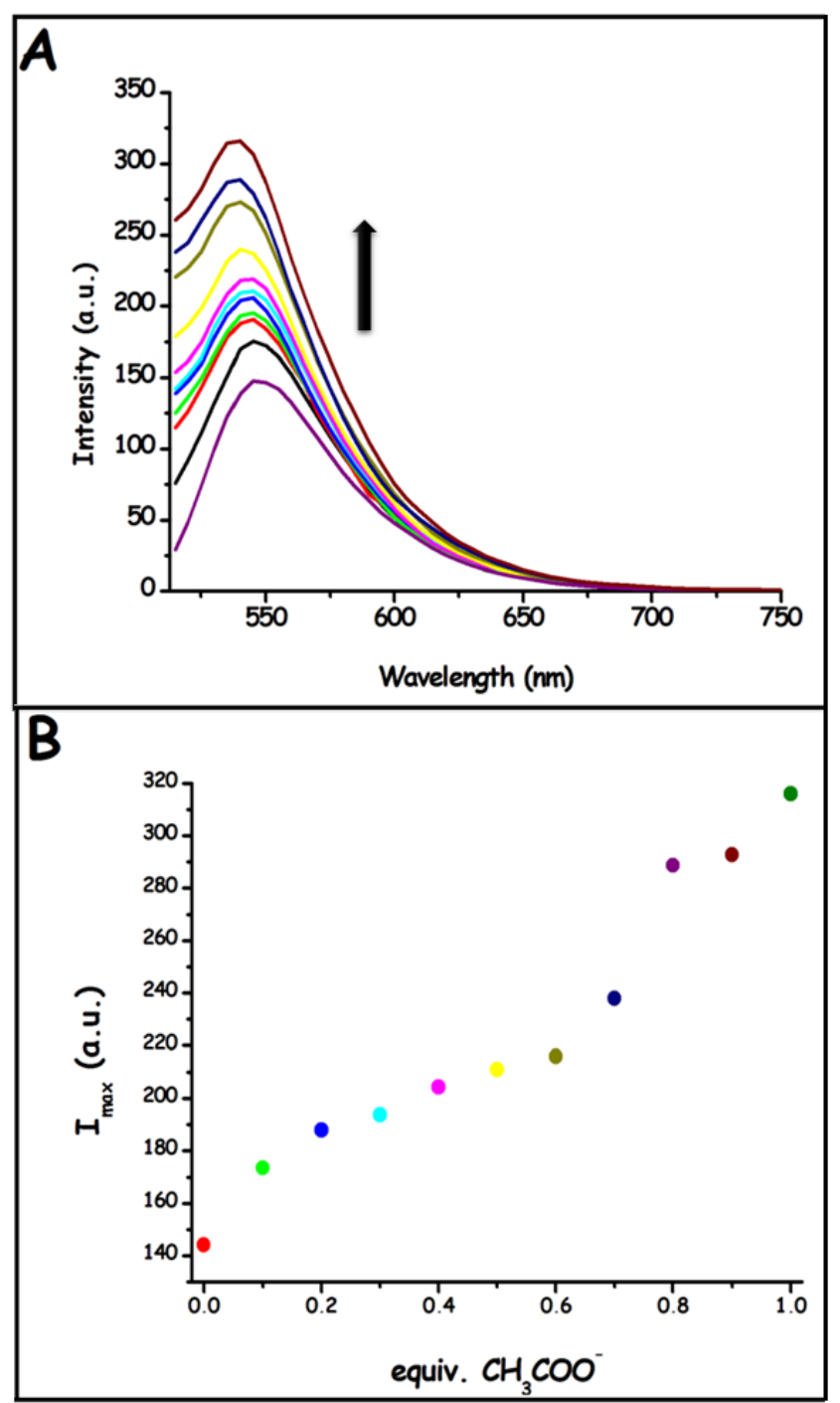

Figure 6. (a) Fluorescence spectra and (b) the emission intensity changes for $\mathbf{1 - Z n}(27 \mu \mathrm{M})$ upon addition various amounts $(0,0.1,0.2,0.3,0.4,0.5,0.6,0.7,0.8$, $0.9,1.0$ equiv.) of $\mathrm{AcO}^{-}$in $\mathrm{CH}_{3} \mathrm{CN}$.

In sharp contrast, the addition of $\mathrm{OH}^{-}$and $\mathrm{F}^{-}$anions resulted in quenching of the emission (Fig. S18 and S19). As the amount of the anions increase, the emission band centered at $545 \mathrm{~nm}$ decreases with a concomitant blue shift around $5 \mathrm{~nm}$. Considering all these changes in the emission spectra of $\mathbf{1 - Z n}$ with $\mathrm{OH}^{-}$and $\mathrm{F}^{-}$anions, it was clear that titration curves reach a plateau for 0.5 equiv. of the anions. Gratifyingly, however, the changes in fluorescence spectrum of $\mathbf{1 - Z n}$ were quite enough to induce visual changes which were easily detectable by the naked-eye. Fig. 7 shows the accompanied visual changes for compounds 1, 1-Zn, 1-Zn-AcO-, 1-Zn- $\mathrm{OH}^{-}$

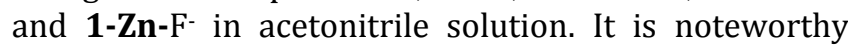
that $\mathbf{1 - Z n}$ allows the fluorescence detection of $\mathrm{AcO}^{-}$ anion among the others. Importantly, none of the other compounds $(\mathbf{1}, \mathbf{1}-\mathbf{N i}$ or $\mathbf{1 - C u})$ were promising for fluorogenic recognition of any of these anions, which makes 1-Zn viable for the detection of $\mathrm{AcO}^{-}$.

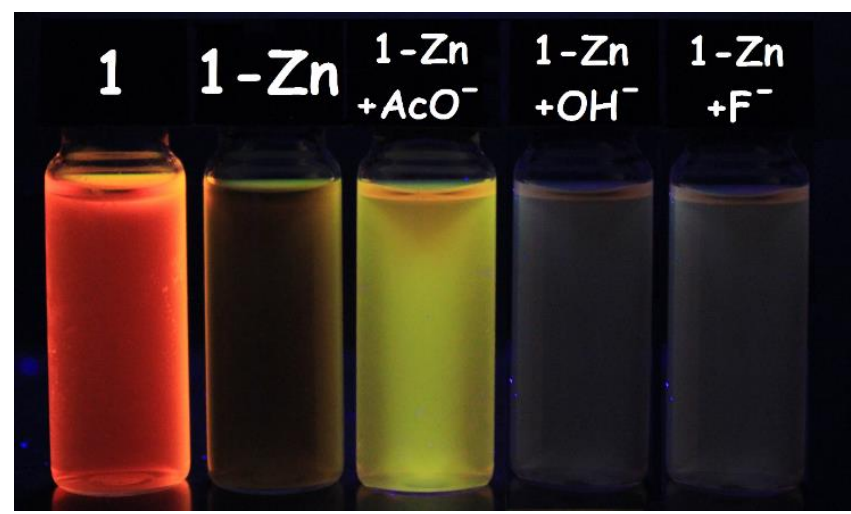

Figure7. Compounds 1, 1-Zn, 1-Zn-AcO-, 1-Zn- $\mathrm{OH}^{-}$and 1-Zn-F- in acetonitrile solution under UV illumination (365 nm).

The fluorescence emission enhancement might be correlated with strong interaction between acetate and metal center of $\mathbf{1 - Z n}$ (Fig. 5b). Moreover, the metal center offers a binding site for $\mathrm{AcO}^{-}$via electrostatic interaction, which may result in high selectivity of $\mathbf{1 - Z n}$ to $\mathrm{AcO}^{-}$anion in acetonitrile media [1]. In addition, the shape and/or size of host and guest are important factors for selective recognition. Ac0- has a triangular structure (states $\mathrm{O}-\mathrm{C}-\mathrm{O}$ about $120^{\circ}$ ) which can provide more stable form and strong complexation between 1Zn and $\mathrm{AcO}^{-}$when compared to $\mathrm{F}^{-}$and $\mathrm{OH}^{-}[1,4,7]$. On the other hand, it should also be considered that $\mathrm{F}^{-}$and $\mathrm{OH}^{-}$can form hydrogen bonding with $\mathrm{N}-\mathrm{H}$ functional group of cyclen ring. The selectivity for $\mathrm{OH}$ - and F- can be related to basicity of anions, and also the interactions between the host and the anionic guests. Furthermore, literature search showed that the basicity and binding affinities of these anions can change with the polarity of solvent or solvent mixtures like ACN, DMSO, DMSO/ $\mathrm{H}_{2} \mathrm{O}$ and the host [49-51]. For example, an association constant for AcO- was found to be $5.11 \times 10^{5} \mathrm{M}^{-1}$ in $\mathrm{ACN}: \mathrm{H}_{2} \mathrm{O} / 95: 5\left(8.32 \times 10^{6}\right.$ in this work) medium by Goswami and Chakrabarty using fluorimetric method [1]. Because of their basicity, AcO-, F- and $\mathrm{OH}-$ can bound more strongly than other anions. In particular, the triangular structure of AcO- may well match with 1$\mathrm{Zn}$ in terms of shape and could form stronger ionic interactions. Consequently, AcO- can be selectively differentiated from other anions based on dissociation constant [17]. The binding constants of 1-Zn with $\mathrm{OH}^{-}, \mathrm{F}^{-}$ and $\mathrm{AcO}^{-}$were calculated from UV-vis and fluorescence titration measurements to reveal the binding properties and selectivity (Table 2). It was found that anion sensing capabilities were found as $\mathrm{AcO}^{-}>\mathrm{F}^{-}>\mathrm{OH}^{-}$in acetonitrile media, respectively. 
Table 2. The association constants of $\mathbf{1 - Z n}$ with $\mathrm{OH}^{-}, \mathrm{F}^{-}$ and $\mathrm{AcO}^{-}$.

\begin{tabular}{ccc}
\hline Compound & $\begin{array}{c}\text { UV-Vis } \\
\text { Method }\end{array}$ & $\begin{array}{c}\text { Fluorescence } \\
\text { Method }\end{array}$ \\
\hline OH$^{-}$ & $1.21 \times 10^{6}$ & $2.77 \times 10^{6}$ \\
F- $^{-}$ & $2.45 \times 10^{6}$ & $2.80 \times 10^{6}$ \\
Ac0- $^{-}$ & $5.68 \times 10^{6}$ & $8.32 \times 10^{6}$ \\
\hline
\end{tabular}

aTetrabuytlammonium salts of anions were used.

Evidently, these changes in the emission profile of $\mathbf{1 - Z n}$ in the presence of $\mathrm{AcO}^{-}$demonstrated that a welldefined complex between $\mathbf{1 - Z n}$ and $\mathrm{AcO}^{-}$was formed. When the JOB study was evaluated to find out the interaction between 1-Zn and acetate, the stoichiometry was found to be 1:2 (Fig. S20). To our knowledge, electrostatic interactions between $\mathrm{Zn}(\mathrm{II})$ center and $\mathrm{AcO}^{-}$anion restricts the free rotation to an extent, thus, providing rigidity to the whole molecule. Furthermore, it is possible to assume that this interaction might affect the energy levels of the frontial orbitals of HOMO and/or LUMO. As a result, PeT process between BODIPY unit and metal binding site might be blocked. The deactivation of PeT process would provide a pathway for radiative decay of the excited state, thus, the fluorescence would be turned on. Moreover, JOB studies were performed for $\mathrm{OH}^{-}$and $\mathrm{F}^{-}$(Fig. S21-S22). The results showed that, both of these anions made similar effects to the fluorescence intensity (decrease). The interaction ratio between $\mathbf{1 - Z n}$ and these anions were also found as 1:2 ratio. Finally, LOD of 1-Zn was calculated as $4.76 \times 10^{-6} \mathrm{M}$ for $\mathrm{AcO}^{-}$(Fig. S24).

\section{Conclusion}

In conclusion, the design and synthesis of a novel cyclen BODIPY dyad and its metal complexes were reported. Furthermore, evaluations of anion recognition features of cyclen BODIPY dyads were described. As far as we know, these compounds represent one of the rare examples of cyclen BODIPY dyads. It was found that 1Zn enables fluorogenic and naked-eye detection of acetate anion. It is considered that the multitude of choices in metal selection will allow extending the applications of this class of compounds. Further studies are ongoing in our laboratory to obtain similar complexes, which can be used in sensing and imaging applications.

\section{Acknowledgement}

F.A. and S.K. thank to the TUBITAK (Scientific and Technological Research Council of Turkey, Grant No. 112T668) and COST (European Cooperation in Science and Technology, CM1006 Action) for financial support. F.A. is indebted to TUBA (Turkish Academy of Sciences) for Outstanding Young Investigator Award (GEBIP). S.K. thanks to TUBITAK and (OYP the Academic Training Programme) of the YOK (Turkish Council of Higher Education) for a scholarship and partial financial support, respectively. Also, the authors thank to Meltem Alp for her assistance in some control experiments. This study was produced from master (postgraduate) thesis of S.K.

\section{References}

[1] Goswami, S. and Chakrabarty, R., "Cu(II) Complex Of An Abiotic Receptor As Highly Selective Fluorescent Sensor For Acetate", Tetrahedron Letters, 50, 59945997, 2009.

[2] Algi, M.P., "A Fluorescent Hypochlorite Probe Built On 1,10-Phenanthroline Scaffold And Its Ion Recognition Features", Journal of Fluorescence, 26, 487-496, 2016.

[3] Algi, M.P., "A Highly Selective Dual Channel Hypochlorite Probe Based On Fluorescein And 1,10Phenanthroline", Tetrahedron, 72, 1558-1565, 2016.

[4] Hosseini, M., Ganjali, M.R., Veismohammadi, B., Faridbod, F., Abkenar, S.D. and Niasari, M. S., "Selective recognition of acetate ion based on fluorescence enhancement chemosensor", Luminescence, 27, 341-345, 2012.

[5] Shang, X., Tian, S., Xi, N., Li, Y., Liang, D., Liu, Y., Yin, Z., Zhang, J. and $\mathrm{Xu}, \mathrm{X}$., "Colorimeric And Fluorescence On-Off Probe For Acetate Anion Based On Thiourea Derivative: Theory And Experiment" Spectrochimica Acta Part A, 103, 276-281, 2013.

[6] Tavallali, H., Rad, G.D., Parhami, A. and Abbasiyan, E., "A New Application Of Bromopyrogallol Red As A Selective And Sensitive Competition Assay For Recognition And Determination Of Acetate Anion In DMSO/Water Media", Dyes and Pigments, 94, 541547, 2012.

[7] Huang, W., Lin, H. and Lin, H., "Fluorescent AcetateSensing In Aqueous Solution", Sensors and Actuators $B$ Chemical, 153, 404-408, 2011.

[8] Liu, G. and Shao, J., "Ratiometric Fluorescence And Colorimetric Sensing of Anion Utilizing Simple Schiff Base Derivatives", Journal of Inclusion Phenomena and Macrocyclic Chemistry, 76, 99-105, 2013.

[9] Kumar, S., Singh, P. and Kumar, S., "1-(2Naphthalenyl) Benzimidazolium Based Fluorescent Probe For Acetate Ion In 90\% Aqueous Buffer" Tetrahedron Letters, 53, 2248-2252, 2012.

[10] Feng, M., Jiang, X., Dong, Z., Zhang, D., Wang, B. and Gao, G., "Selective Recognition Of Acetate Ion By Perimidinium-Based Receptors", Tetrahedron Letters, 53, 6292-6296, 2012.

[11] Goswami, S., Maity, S., Das, A.K. and Maity, A.C., "Single Chemosensor For Highly Selective Colorimetric And Fluorometric Dual Sensing of Cu(II) As Well As 'Nirf' To Acetate Ion", Tetrahedron Letters, 54, 6631-6634, 2013.

[12] Kumar, M.S., Kumar, S.L. and Sreekanth, A., "An Efficient Triazole-Based Fluorescent "Turn-On" Receptor For Naked-Eye Recognition of $\mathrm{F}^{-}$And $\mathrm{AcO}^{-}$: Uv-Visible, Fluorescence And ${ }^{1} \mathrm{H}$ NMR 
Studies", Material Science and Engineering C, 33, 3346-3352, 2013.

[13] Xu, K., Kong, H., Li, Q., Song, P., Dai, Y. and Yang, L., "Novel Anthracene-Based Fluorescent Sensor For Selective Recognition of Acetate Anions In Protic Media", Spectrochimica Acta Part A, 137, 957-961, 2015.

[14] Sharma, D., Kuba, A., Thomas, R., Kumar, S.K.A., Kuwar, A., Choi, H., J. and Sahoo, S.K., "Acetate Selective Fluorescent Turn-On Sensors Derived Using Vitamin B6 Cofactor Pyridoxal-5-Phosphate", Spectrochimica Acta Part A, 157, 110-115, 2016.

[15] Liu, G. and Shao, J., "Selective Ratiometric Fluorescence Detection of Acetate Based On A Novel Schiff Base Derivative", Journal of Fluorescence, 22, 397-401, 2012.

[16] Hu, Z., Q., Wang, X.M., Feng, Y.C., Ding, L., Li, M. and Lin, C.S., "A Novel Colorimetric And Fluorescent Chemosensor For Acetate Ions In Aqueous Media Based On A Rhodamine 6g-Phenylurea Conjugate In The Presence of Fe(III) Ions", Chemistry Communications, 47, 1622-1624, 2011.

[17] Shang, X., Yuan, J., Du, Z., Wang, Y., Jia, S., Han, J., Li, Y., Zhang, J. and $\mathrm{Xu}, \mathrm{X}$., "Determination Limit Of Fluorescence Turn-On Probes For The Acetate Anion", Helvetica Chimica Acta, 96, 719-731, 2013.

[18] Bhuyan, M., Katayev, E., Stadlbauer, S., Nonaka, H., Ojida, A., Hamachi, I. and König, B., "Rigid Luminescent Bis-Zinc(Ii)-Bis-Cyclen Complexes For The Detection of Phosphate Anions And Non-Covalent Protein Labeling In Aqueous Solution", European Journal of Organic Chemistry, 2807-2817, 2011.

[19] Li, S., Chen, J.X., Xiang, Q.X., Zhang, L.Q., Zhou, C., H., Xie, J.Q., Yu, L. and Li, F.Z., "The Synthesis And Activities Of Novel Mononuclear or Dinuclear Cyclen Complexes Bearing Azole Pendants As Antibacterial And Antifungal Agents", European Journal of Medicinal Chemistry, 84, 677-686, 2014.

[20] Aoki, S., Jikiba, A., Takeda, K. and Kimura, E., "A Zinc(II) Complex-Conjugated Polymer For Selective Recognition And Separation Of Phosphates", Journal of Physical Organic Chemistry, 17, 89-497, 2004.

[21] Gruber, B., Stadlbauer, S., Woinaroschy, K. and König, B., "Luminescent Vesicular Receptors For The Recognition of Biologically Important Phosphate Species", Organic \& Biomolecular Chemistry,8, 3704-3714, 2010.

[22] Huang, X.H., Lu, Y., He, Y.B. and Chen, Z.H., "A Metal-Macrocycle Complex as A Fluorescent Sensor For Biological Phosphate Ions In Aqueous Solution" European Journal of Organic Chemistry, 1921-1927, 2010.

[23] Jose, D.A., Stadlbauer, S. and König, B., "Polydiacetylene-Based Colorimetric SelfAssembled Vesicular Receptors For Biological
Phosphate Ion Recognition", Chemistry - A European Journal, 1, 7404-7412, 2009.

[24] Du. J., Wang, X., Jia, M., Li, T., Mao, J. and Guo, Z., "Recognition of Phosphate Anions In Aqueous Solution By A Dinuclear Zinc(II) Complex Of A Cyclen-Tethered Terpyridine Ligand", Inorganic Chemistry Communications, 11, 999-1002, 2008.

[25] Siters, K.E., Sander, S.A., Devlin, J.R. and Morrow, J.R., "Bifunctional Zn(II) Complexes For Recognition Of Non-Canonical Thymines In DNA Bulges And GQuadruplexes", Dalton Transactions, 44, 3708-3716, 2015.

[26] del Mundo, I.M.A., Siters, K.E., Fountain, M.A. and Morrow, J.R., "Structural Basis For Bifunctional Zinc(II) Macrocyclic Complex Recognition Of Thymine Bulges In DNA", Inorganic Chemistry, 51, 5444-5457, 2012.

[27] Kimura, E., Kikcuhi, M., Kitamura, H. and Koike, T., "Selective And Efficient Recognition Of Thymidylylthymidine (Tpt) By Bis(Znii-Cyclen) And Thymidylylthymidylylthymidine (Tptpt) By Tris(Znii-Cyclen) At Neutral pH In Aqueous Solution", Chemistry A European Journal, 5(11), 3113-3123, 1999.

[28] Micoli, A., Soriano, M.L., Traboulsi, H., Quintana, M. and Prato, M., "Zn"I-Cyclen As A Supramolecular Probe For Tagging Thymidine Nucleosides On Carbon Nanotubes", European Journal of Organic Chemistry, 18, 3685-3690, 2013.

[29] Zheng, Z. and Spiccia, L., "OFF-ON Fluorescent Detection Of Thymidine Nucleotides By A Zinc(II)Cyclen Complex Bearing Two Diagonal Pyrenes", Chemistry A European Journal, 15, 12941-12944, 2009.

[30] Gruber, B., Kataev, E., Aschenbrenner, J., Stadlbuer, S. and König, B., "Vesicles And Micelles From Amphiphilic Zinc(II)-Cyclen Complexes As Highly Potent Promoters Of Hydrolytic DNA Cleavage", Journal of American Chemical Society, 133, 2070420707, 2011.

[31] Kolemen, S. and Akkaya, E.U., "Reaction-Based BODIPY Probes For Selective Bio-Imaging", Coordination Chemistry Reviews, 354, 121-134, 2018.

[32] Laudet, A. and Burgess, K., "BODIPY Dyes And Their Derivatives: Syntheses And Spectroscopic Properties", Chemical Reviews, 107, 4891-4932, 2007.

[33] Ulrich, G. and Ziessel, R., "The Chemistry Of Fluorescent Bodipy Dyes: Versatility Unsurpassed", Angewandte Chemie International Edition, 47, 11841201, 2008.

[34] Antina, E.V., Bumagina, N.A., V'yugin, A.I. and Solomonov, A.V., "Fluorescent Indicators Of Metal Ions Based On Dipyrromethene Platform", Dyes and Pigments, 136: 368-381, 2017. 
[35] Lu, H., Mack, J., Nyokong, T., Kobayashi, N., and Shen, Z., "Optically Active BODIPYs", Coordination Chemistry Reviews, 318, 1-15, 2016.

[36] Benstead, M., Mehl, G.H. and Boyle, R.W., "4,4'Difluoro-4-bora-3a,4a-diaza-s-indacenes (BODIPYs) As Components of Novel Light Active Materials", Tetrahedron, 67, 3573-3601, 2011.

[37] Guliyev, R., Ozturk, S., Kostereli, Z. and Akkaya, E.U., "From Virtual To Physical: Integration Of Chemical Logic Gates", Angewandte Chemie International Edition, 50, 9826-9831, 2011.

[38] Kolemen, S., Ișık, M., Kim, G.M., Kim, D., Geng, H., Buyuktemiz, M., Karatas, T., Zhang, X-F., Dede, Y., Yoon, J. and Akkaya, E.U., "Intracellular Modulation Of Excited-State Dynamics In A Chromophore Dyad: Differential Enhancement of Photocytotoxicity Targeting Cancer Cells", Angewandte Chemie International Edition, 54, 5340-5344, 2015.

[39] Degirmenci, A. and Algi, F., "Synthesis, Chemiluminescence And Energy Transfer Efficiency Of 2,3-Dihydrophthalazine-1,4-Dione And BODIPY Dyad", Dyes and Pigments, 140, 92-99, 2017.

[40] Karakaya, S. and Algi, F., "A Novel Dual Channel Responsive Zinc(II) Probe", Tetrahedron Letters, 55(40), 5555-5559,2014.

[41] Pamuk, M. and Algi, F., "Synthesis Of A Novel On/Off Fluorescent Cadmium(II) Probe", Tetrahedron Letters, 53(51), 7010-7012, 2012.

[42] Ekmekci, Z., "Highly Selective Fluorescence 'TurnOff' Sensors For $\mathrm{Cu}^{2+}$ In Aqueous Environments", Tetrahedron Letters, 56 1878-1881, 2015.

[43] Li, Z, Geng, Z.R., Zhang, C., Wang, X.B. and Wang Z.L., "BODIPY-Based Azamacrocyclic Ensemble For Selective Fluorescence Detection And Quantification Of Homocysteine In Biological Applications", Biosensensors and Bioelectronics, 72, 1-9, 2015.

[44] Wu, H., Krishnakumar, S., Yu, J., Liang, D., Qi, H., Lee, Z.W., Deng, L.W. and Huang, D., "Highly Selective And Sensitive Near-Infrared-Fluorescent Probes For The Detection Of Cellular Hydrogen Sulfide And The Imaging of $\mathrm{H}_{2} \mathrm{~S}$ In Mice", Chemistry - An Asian Journal, 9, 3604-3611, 2014.

[45] Valkova, Y.A., Brizet, B., Harvey, P.D., Averin, A.D., Goze, C. and Denat, F., "BODIPY Dyes Functionalized With Pendant Cyclic And Acyclic Polyamines", European Journal of Organic Chemistry, 2013, 42704279, 2013.

[46] Valkova, Y.A., Brizet, B., Harvey, P.D., Denat, F and Goze, C., "High Yield $\mathrm{S}_{\mathrm{N}} \mathrm{Ar}$ on 8-Halogenophenyl-BODIPY with Cyclic and Acyclic Polyamines", European Journal of Organic Chemistry, 2014, 2268-2274, 2014.

[47] Wilson, J.M., "Synthesis of Biologically Active Heterocyclic Compounds", PhD Dissertation, University of Glasgow, 2007.
[48] Kalai, T. and Hideg, K., "Synthesis Of New, BodipyBased Sensors And Labels", Tetrahedron, 62, 1035210360, 2006.

[49] Srikala, P., Tarafder, K. and Trivedi, D.R., "Design and Synthesis of A New Organic Receptor And Evaluation Of Colorimetric Anion Sensing Ability In Organo-Aqueous Medium", Spectrochimica Acta Part A, 170, 29-38, 2017.

[50] Zhao, L.Y., Wang, G.K., Chen, J.H., Zhang, L.M., Liu, B., Zhang, J.F., Zhao, Q.H. and Zhou, Y., "1,8Naphthalimide-Based Visible Colorimetric Sensor For The Selective Sensing Of Fluoride, Acetate and Hydroxyl Anions", Journal of Fluorine Chemistry, 158, 53-59, 2014.

[51] Farrugia, K.N., Makuc, D., Podborska, A., Szacilowski, K., Plavec, J. and Magri, D.C., "Colorimetric Naphthalene-Based Thiosemicarbazide Anion Chemosensor With An Internal Charge Transfer Mechanism", European Journal of Organic Chemistry, 25, 4415-4422, 2016. 
Supporting Information

\title{
SYNTHESIS OF CYCLEN BODIPY DYAD AND ITS METAL COMPLEXES: EVALUATION OF ANION RECOGNITION FEATURES
}

\author{
Fatih ALGI ${ }^{1, *}$ and Serkan KARAKAYA2
}

1 Department of Biotechnology and Molecular Biology \& ASUBTAM MemduhBilmezBioNanoTech Lab. Aksaray University, TR-68100 Aksaray, Turkey.

2Laboratory of Organic Materials (LOM), Canakkale Onsekiz Mart University, Canakkale TR-17100, Turkey.

E-mail: falgi@aksaray.edu.tr, Telephone: +903822882151, Fax: +903822882185

Table of Contents

1. NMR and Mass Spectra for compounds

2. Additional Graphs and Data $80-91$

$.92-99$ 
1. NMR, ESI-MS and MALDI TOF MS Spectra for compounds

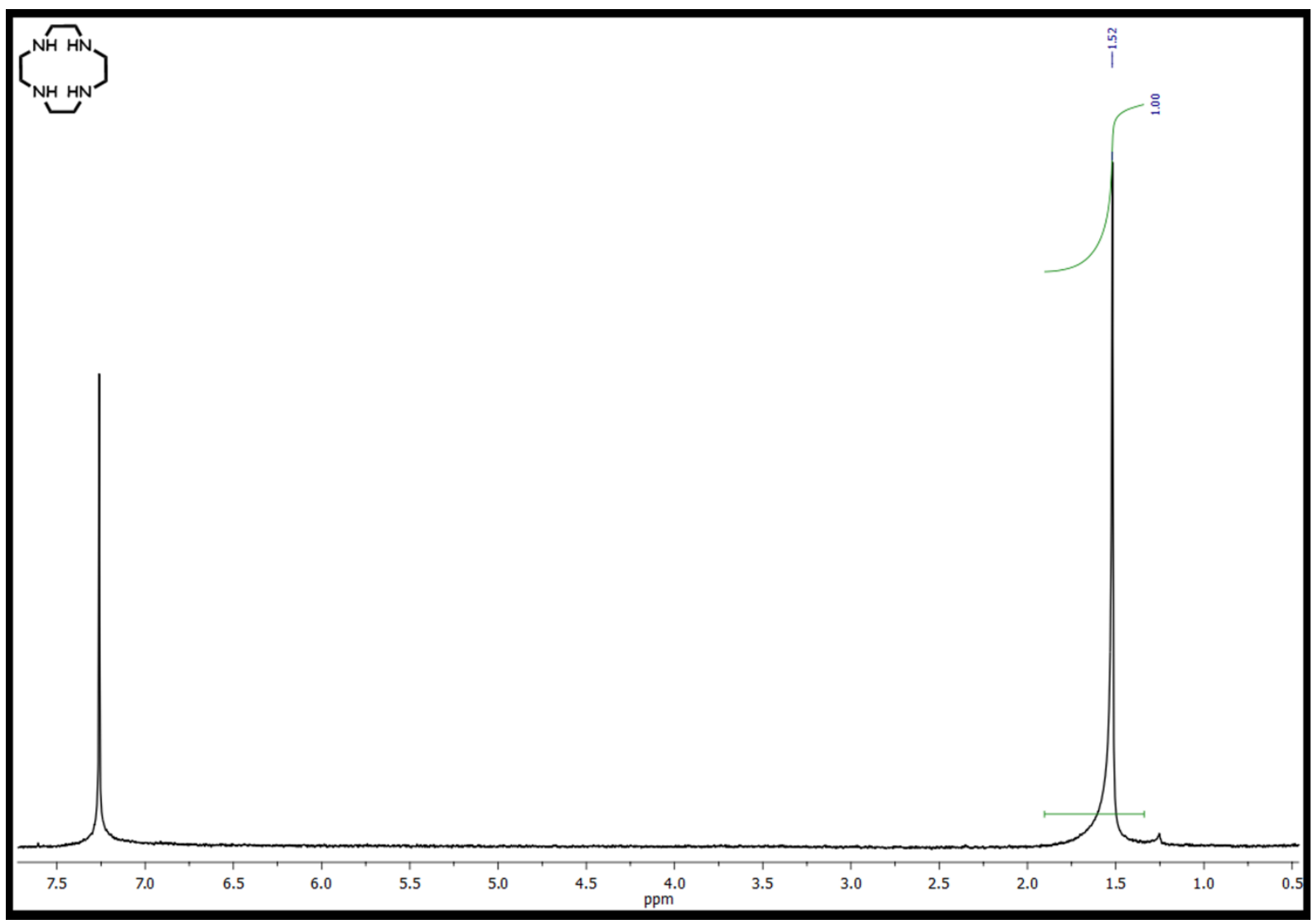

Figure S1. ${ }^{1} \mathrm{H}$ NMR spectrum of 2 in $\mathrm{CDCl}_{3}$. 


$$
\frac{D}{2}
$$




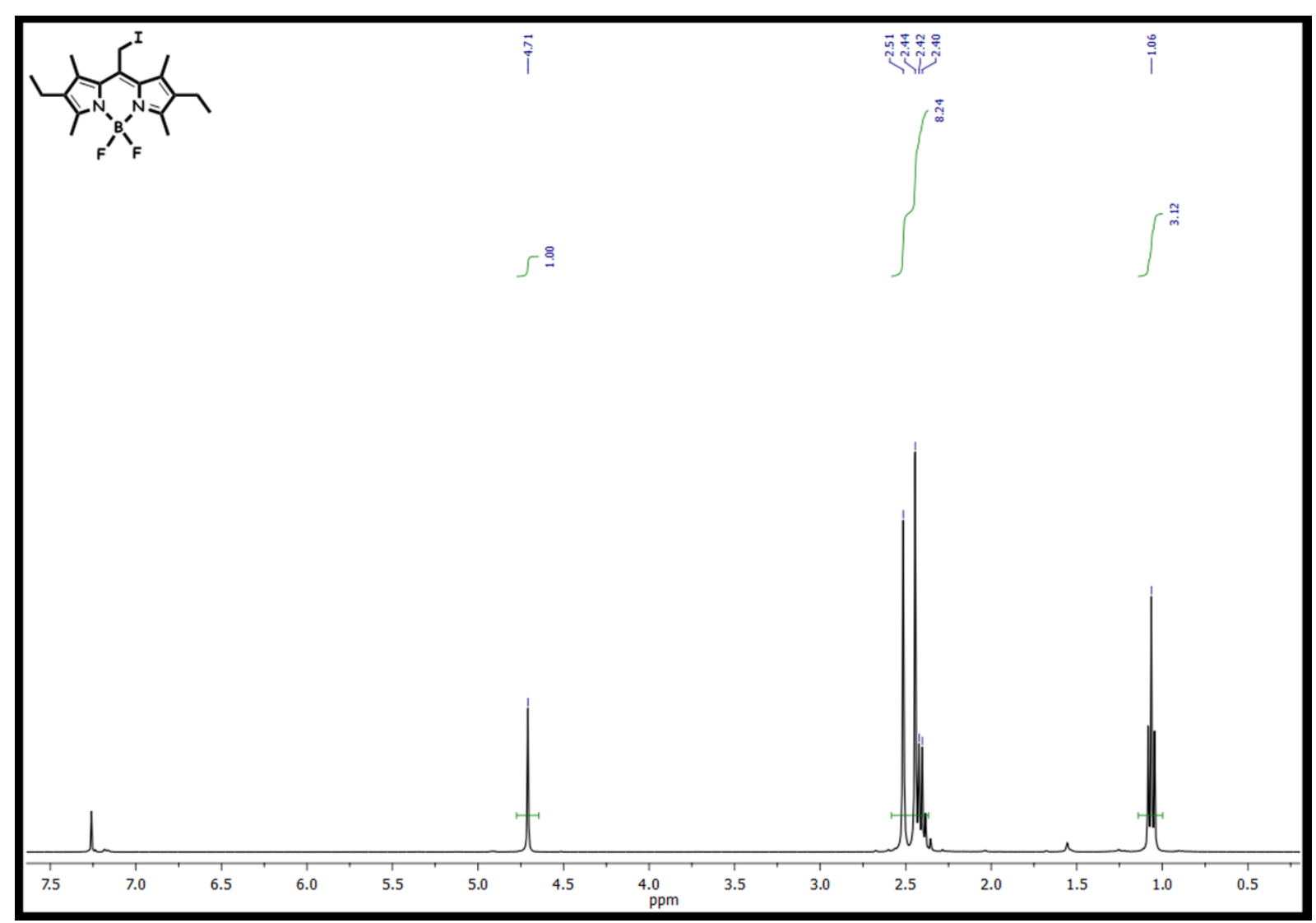

Figure S4..$^{1} \mathrm{H}$ NMR spectrum of 3 in $\mathrm{CDCl}_{3}$. 


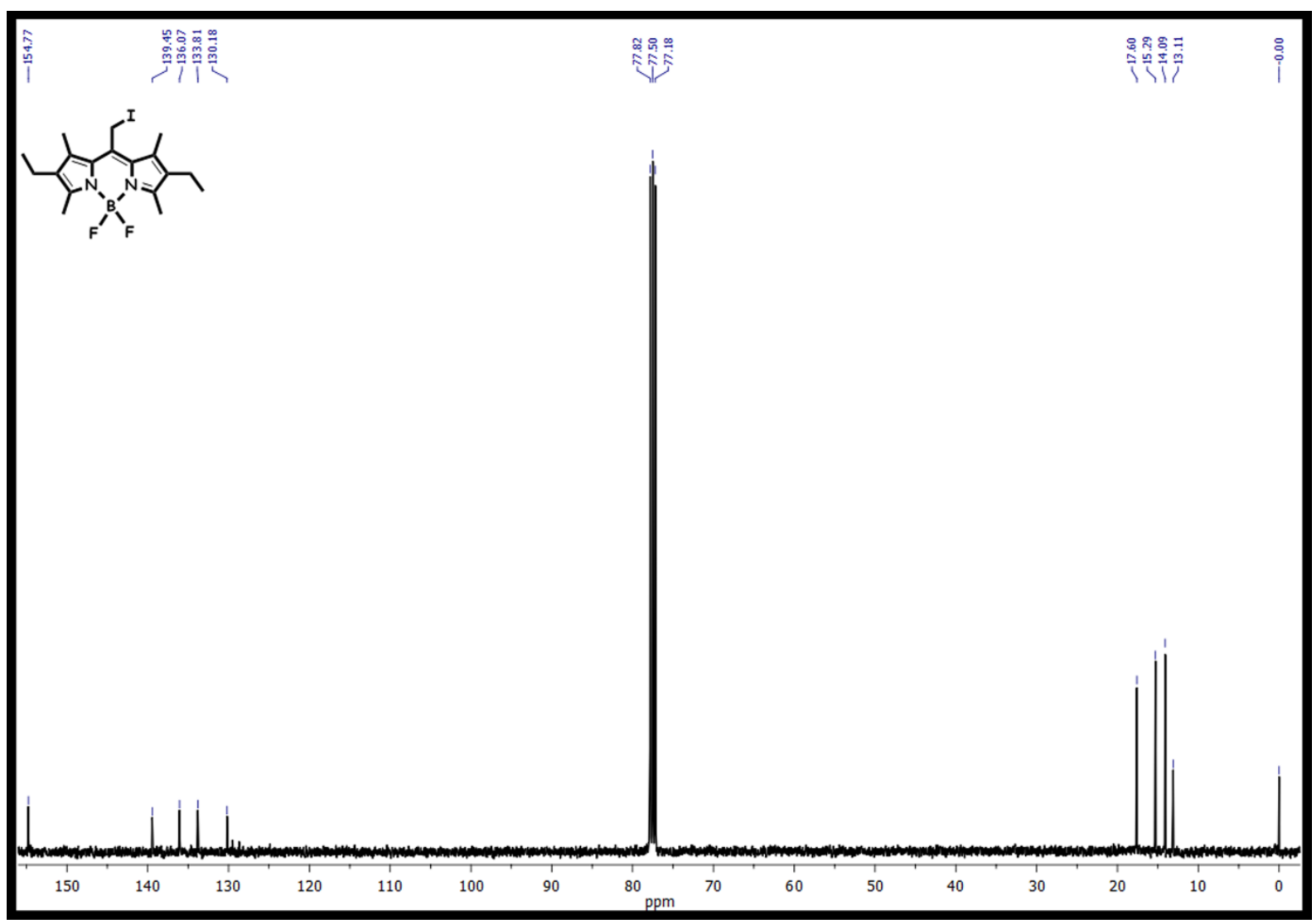

Figure S5. ${ }^{13} \mathrm{C}$ NMR spectrum of 3 in $\mathrm{CDCl}_{3}$. 


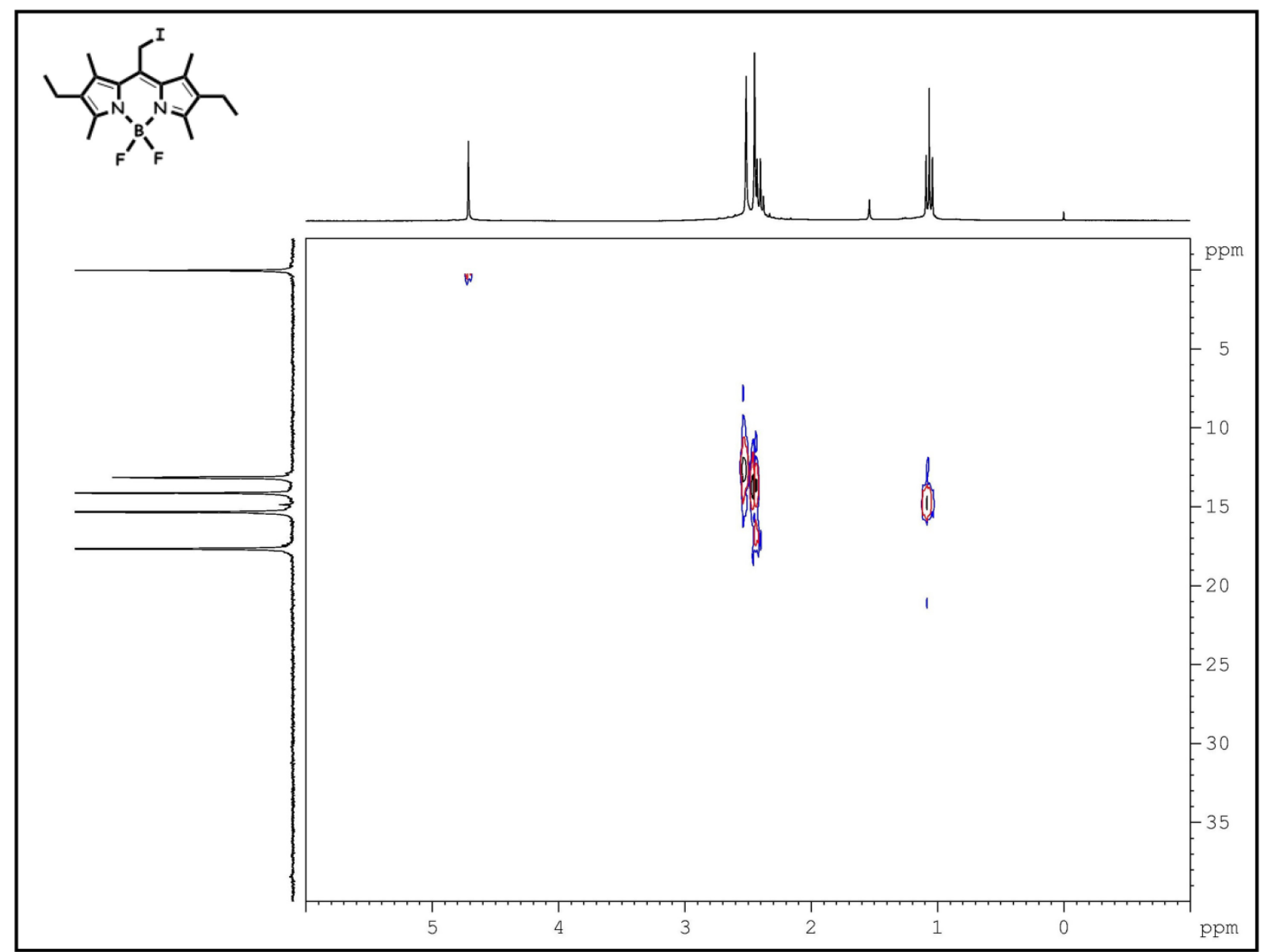

Figure S6. HMQC spectrum of 3 in $\mathrm{CDCl}_{3}$. 


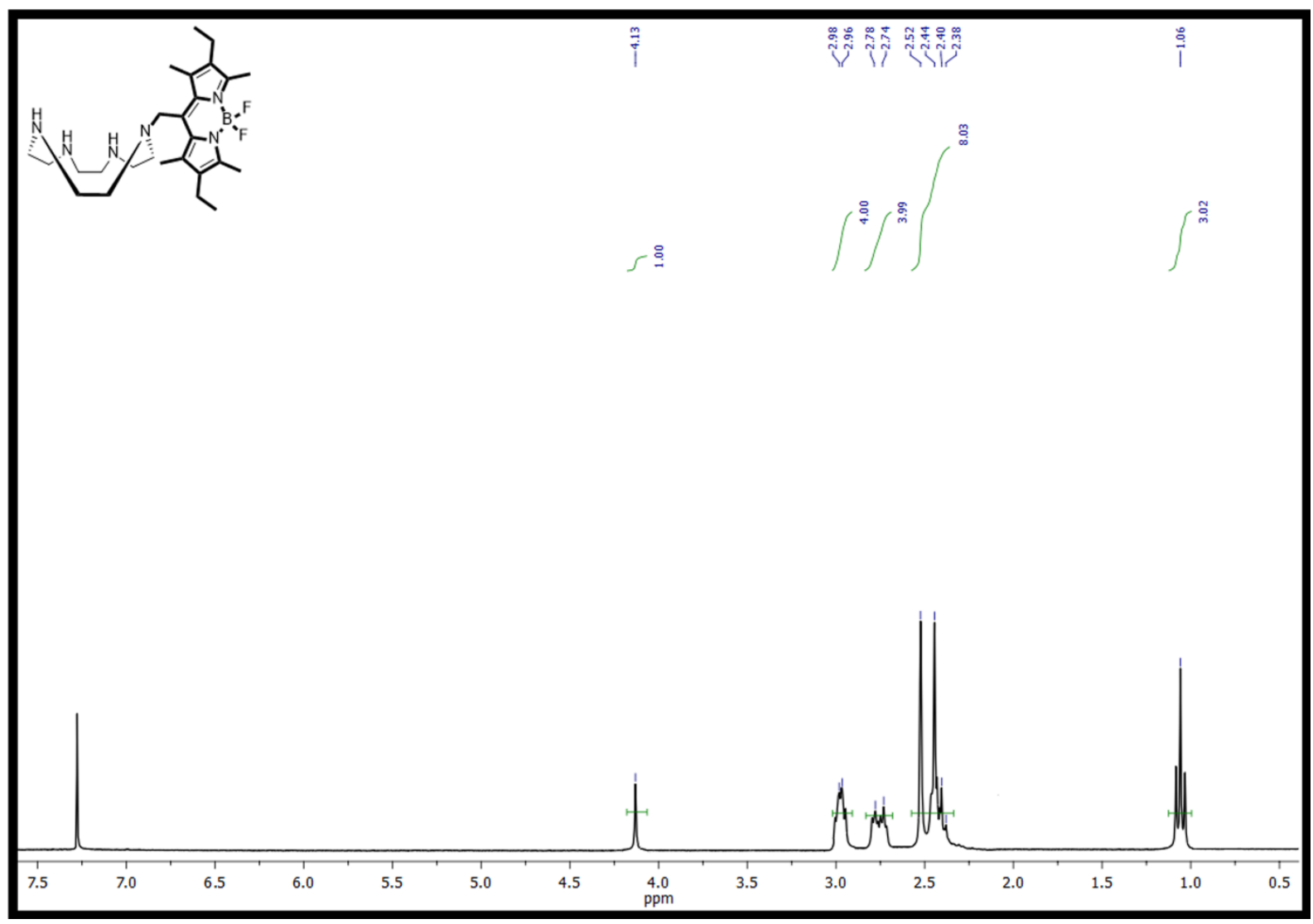

Figure S7. ${ }^{1} \mathrm{H}$ NMR spectrum of $\mathbf{1}$ in $\mathrm{CDCl}_{3}$. 


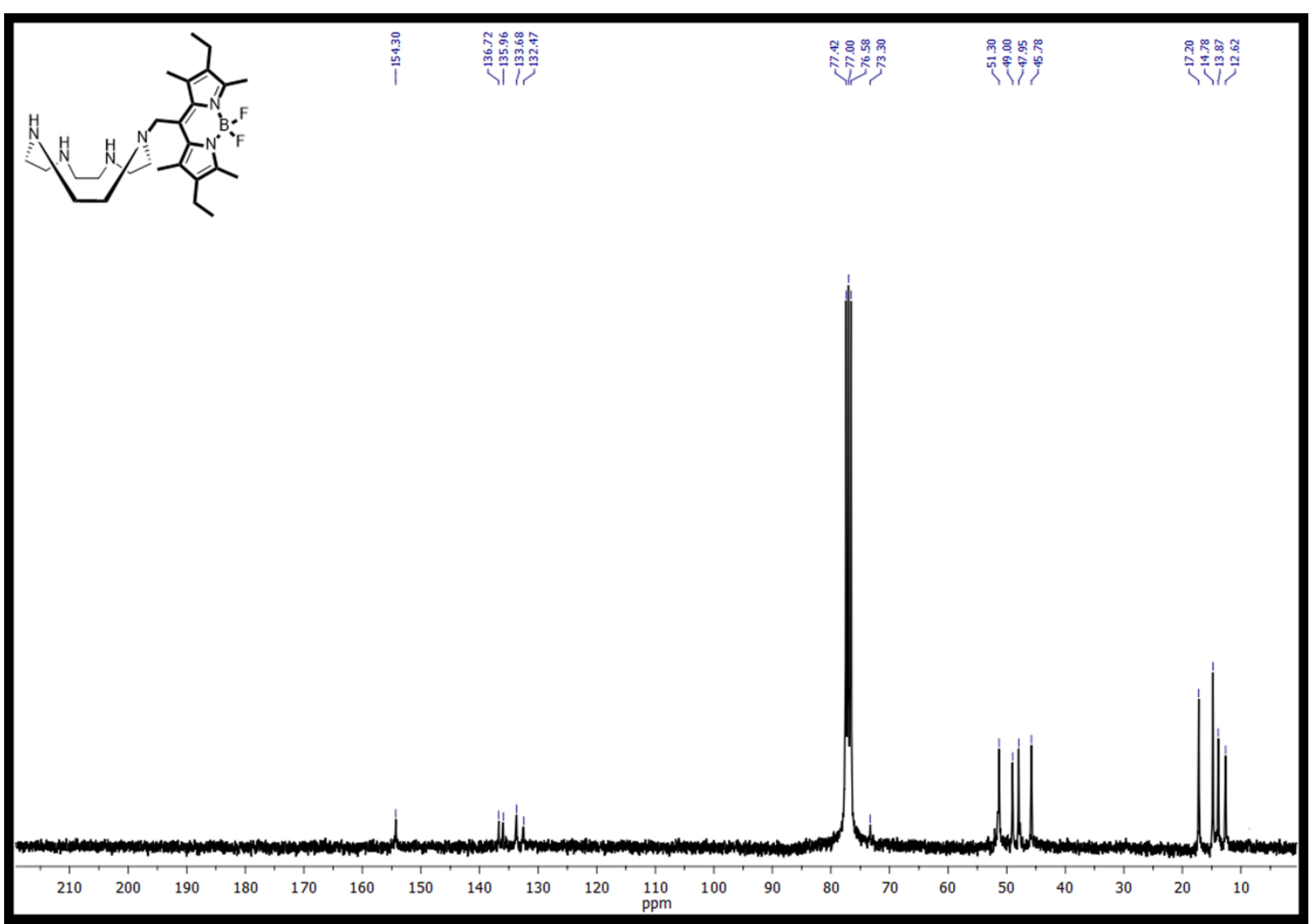

Figure S8. ${ }^{13} \mathrm{C}$ NMR spectrum of $\mathbf{1}$ in $\mathrm{CDCl}_{3}$. 


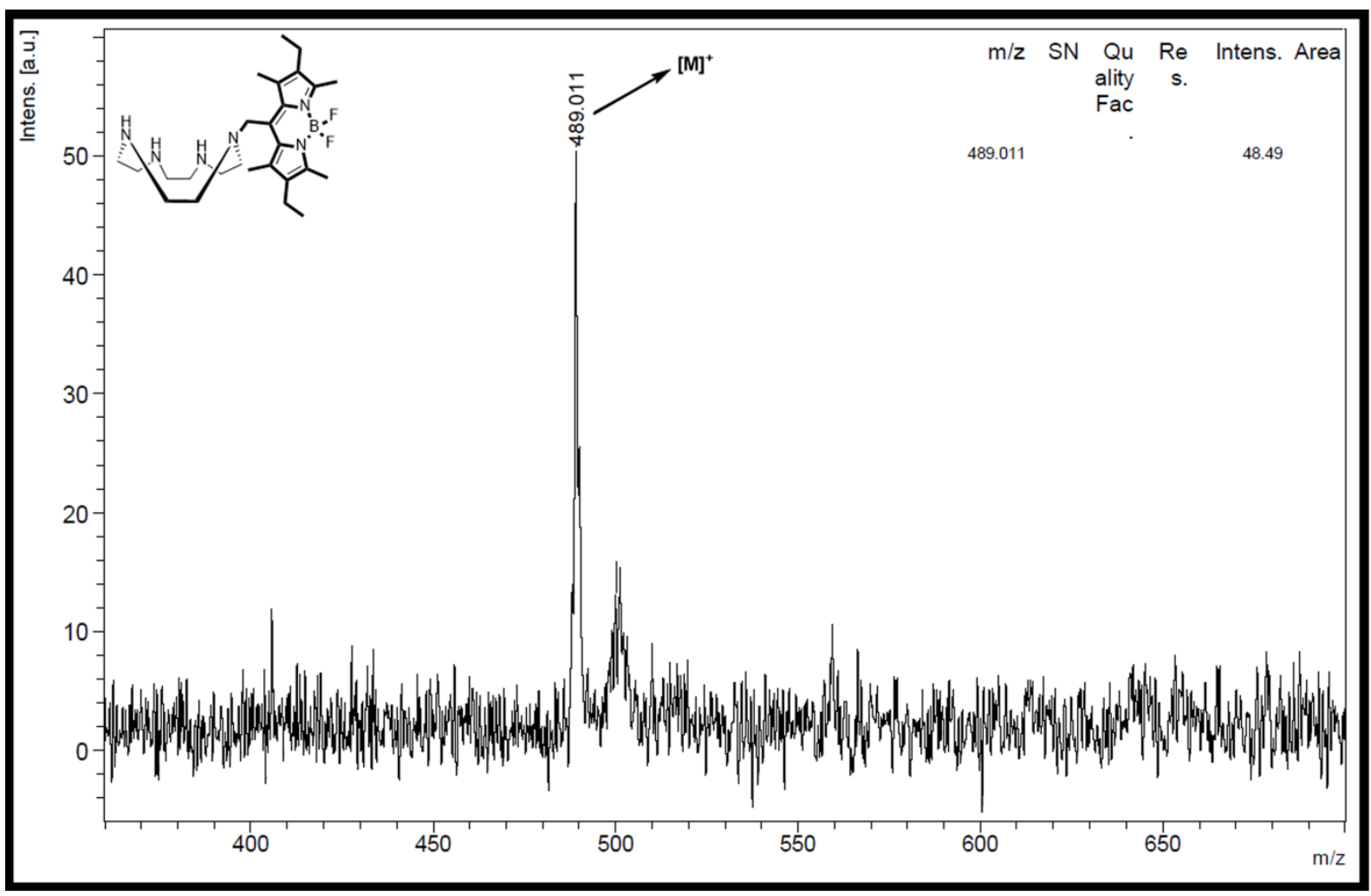

Figure S9. MALDI TOF MS spectrum of $\mathbf{1}$. 


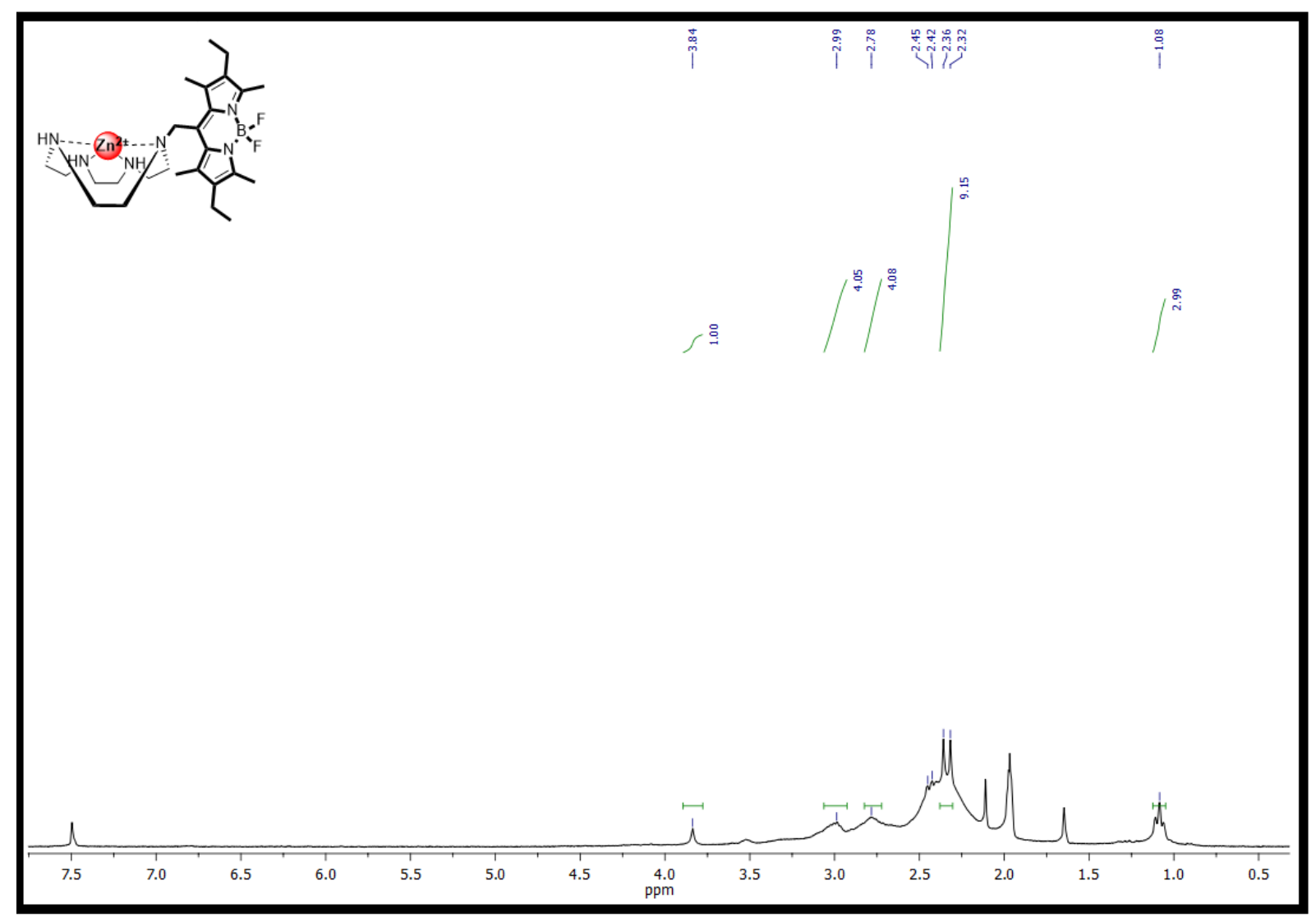

Figure S10. ${ }^{1} \mathrm{H}$ NMR spectrum of $\mathbf{1 - Z n}$ in mixture of $\mathrm{CD}_{3} \mathrm{CN}$ and $\mathrm{CDCl}_{3}$.

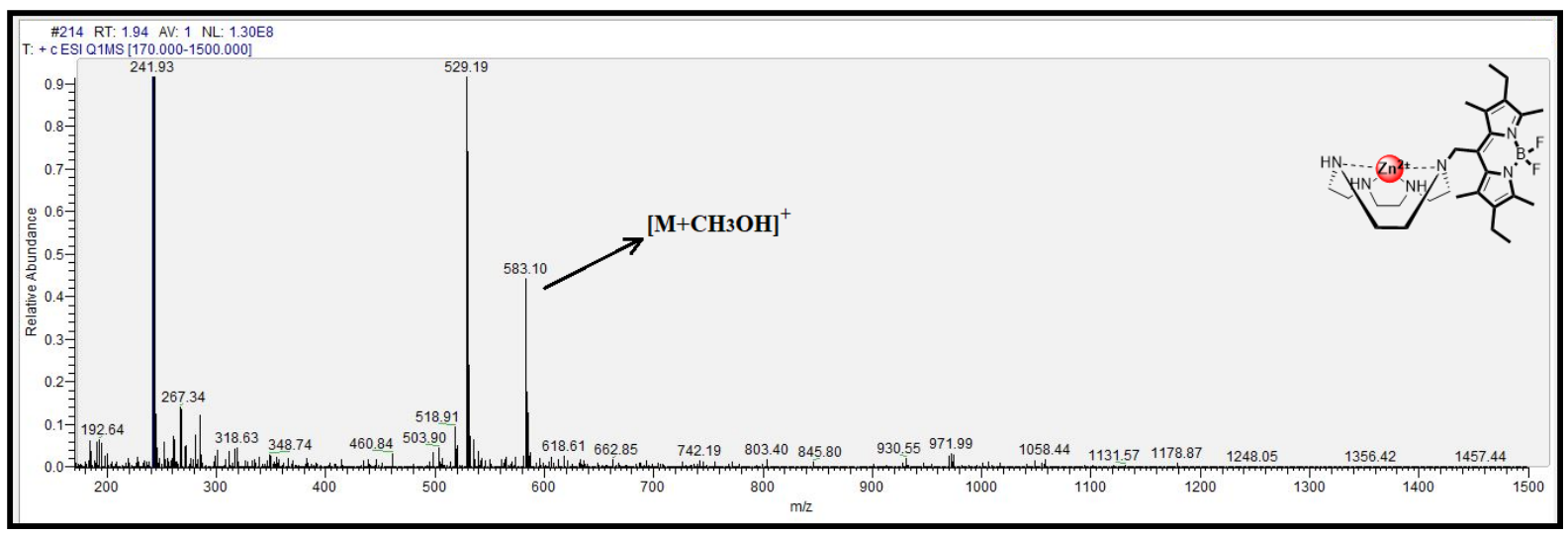

Figure S11. LC-MS spectrum of 1-Zn. 


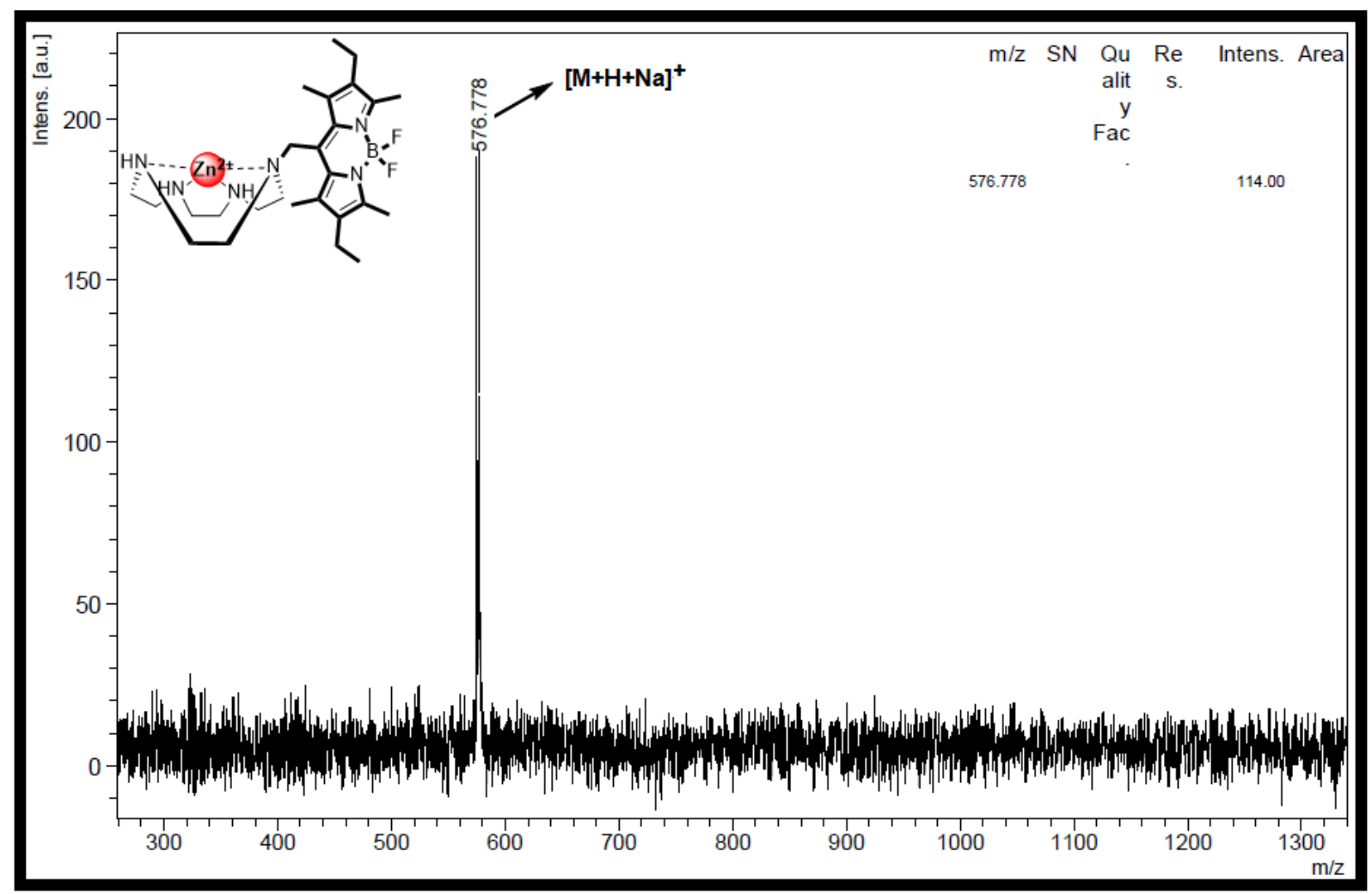

Figure S12. MALDI TOF MS spectrum of 1-Zn. 


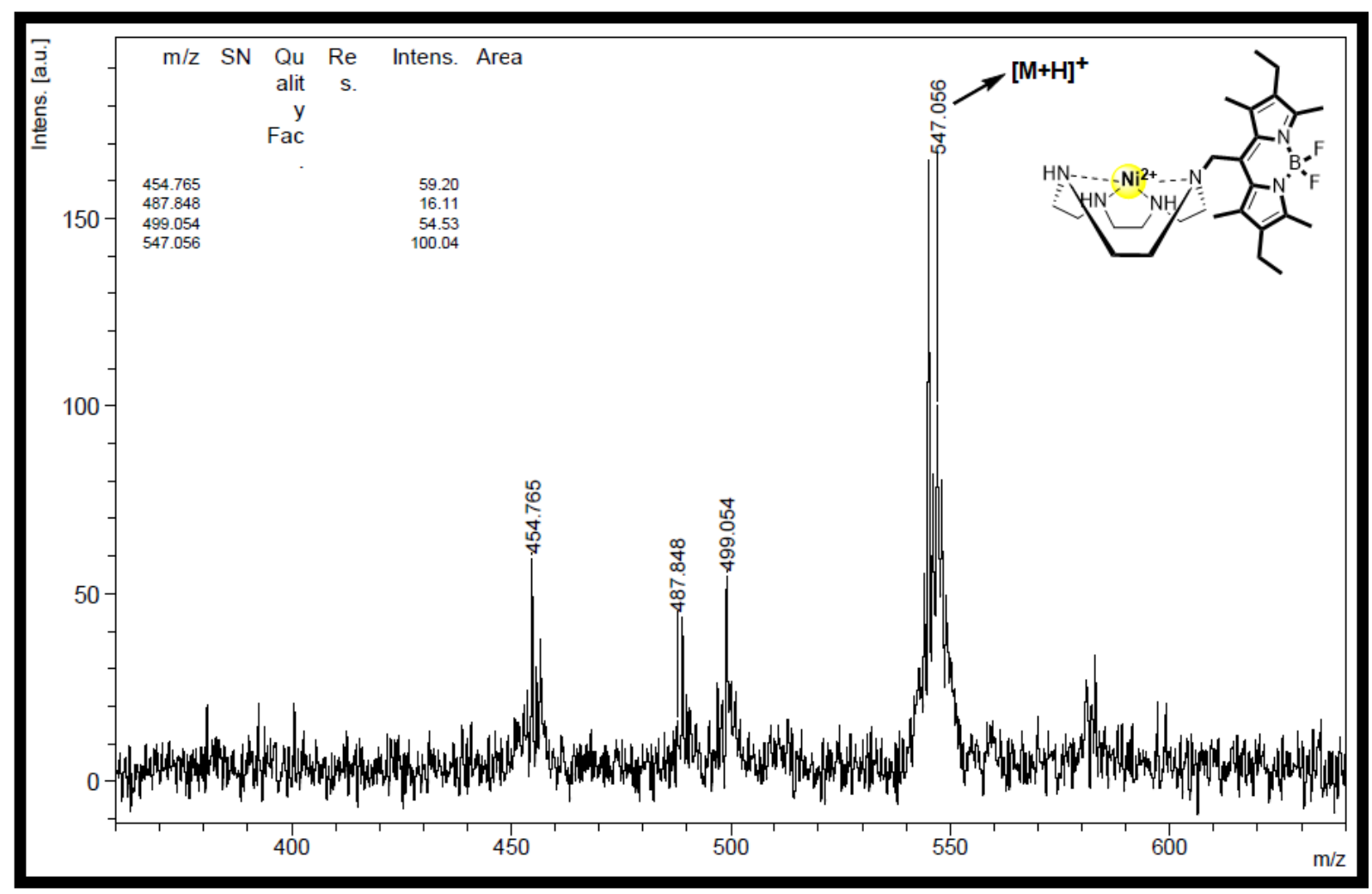

Figure S13. MALDI TOF MS spectrum of 1-Ni. 


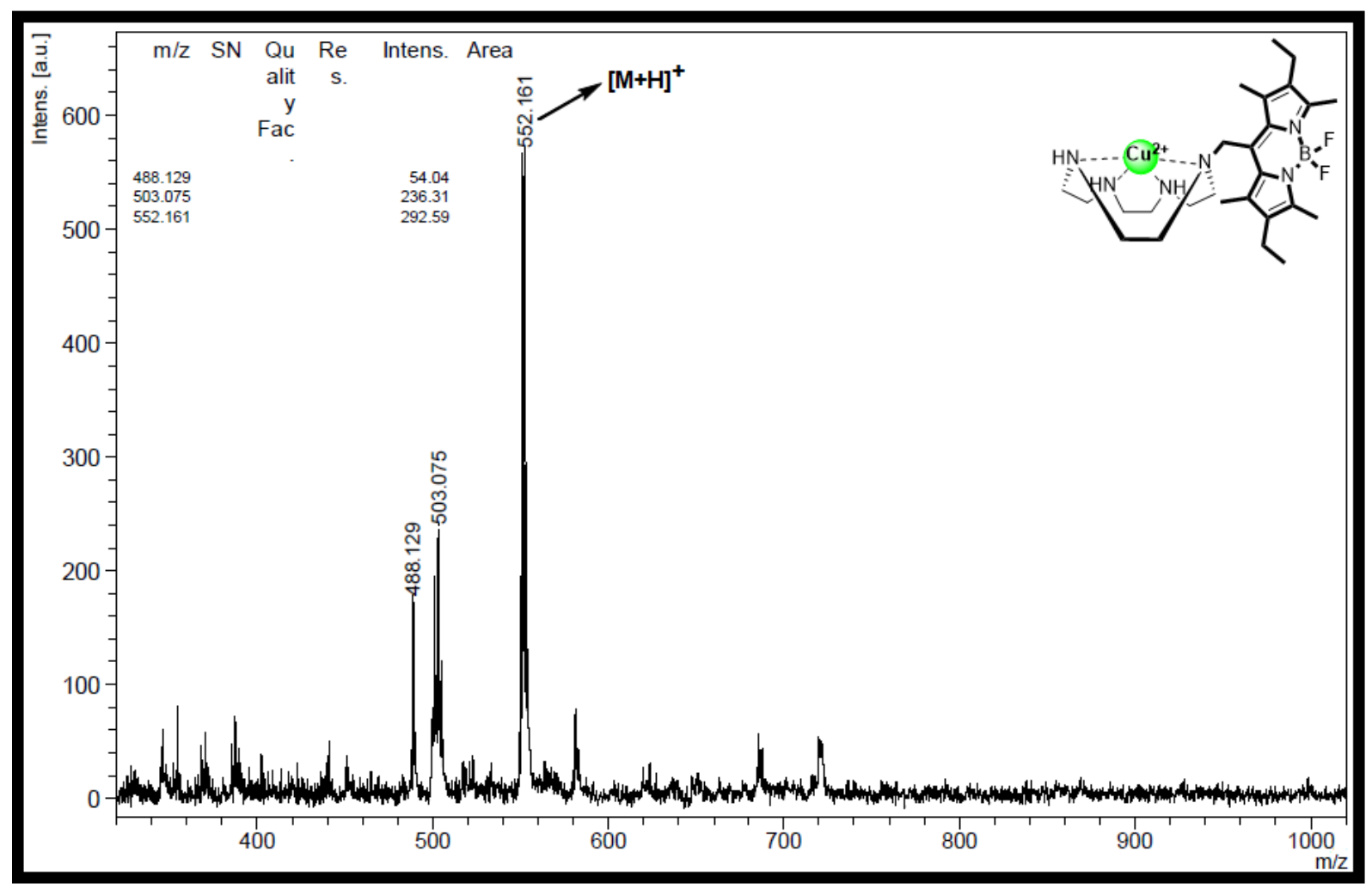

Figure S14. MALDI TOF MS spectrum of 1-Cu. 


\section{Additional Graphs and Data}

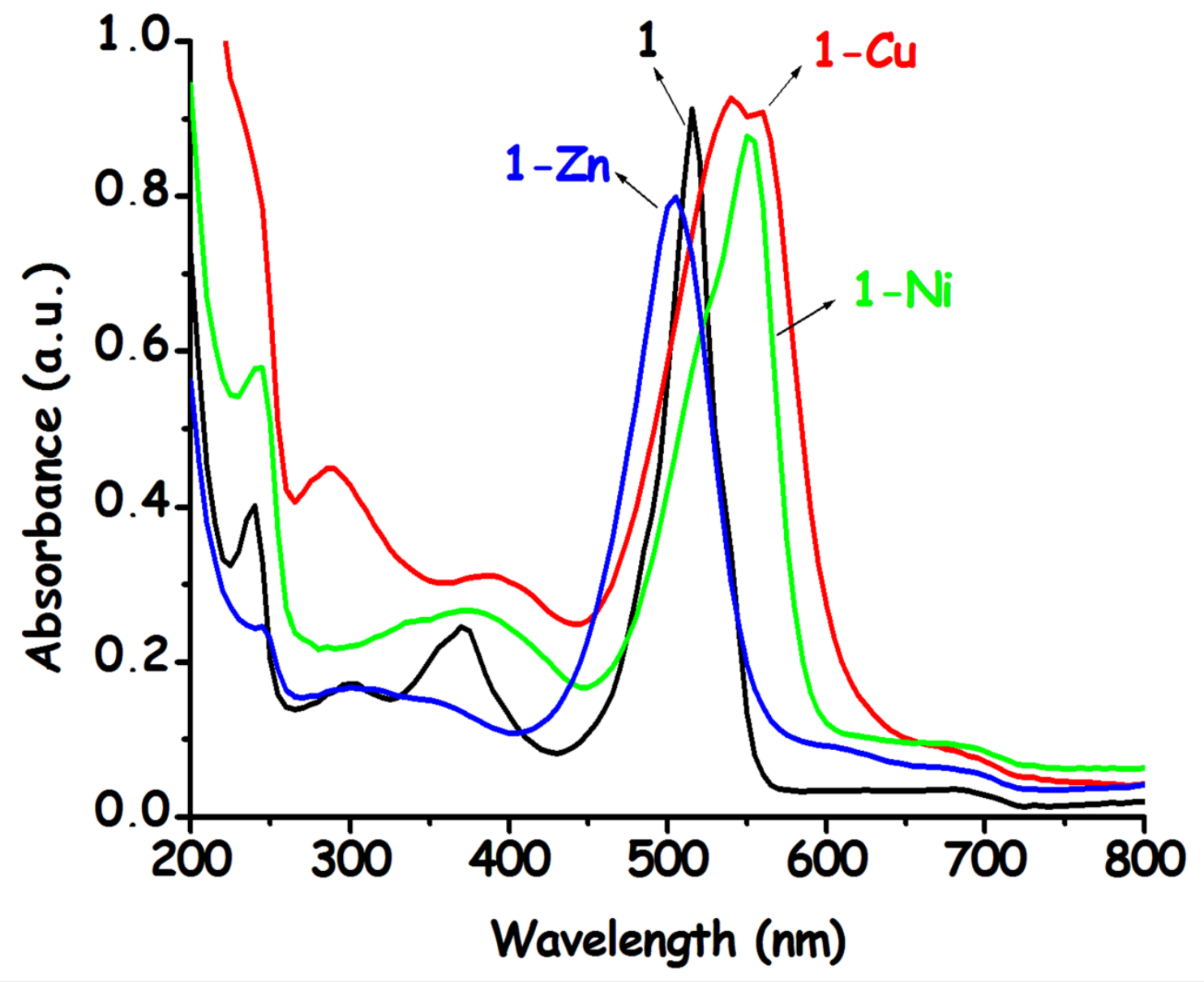

Figure S15.Absorbtion spectra of compounds $1(8 \mu \mathrm{M}), \mathbf{1 - Z n}(12 \mu \mathrm{M}), \mathbf{1 - N i}(24 \mu \mathrm{M})$ and 1-Cu $(30 \mu \mathrm{M})$ in $\mathrm{CH}_{3} \mathrm{CN}$. 


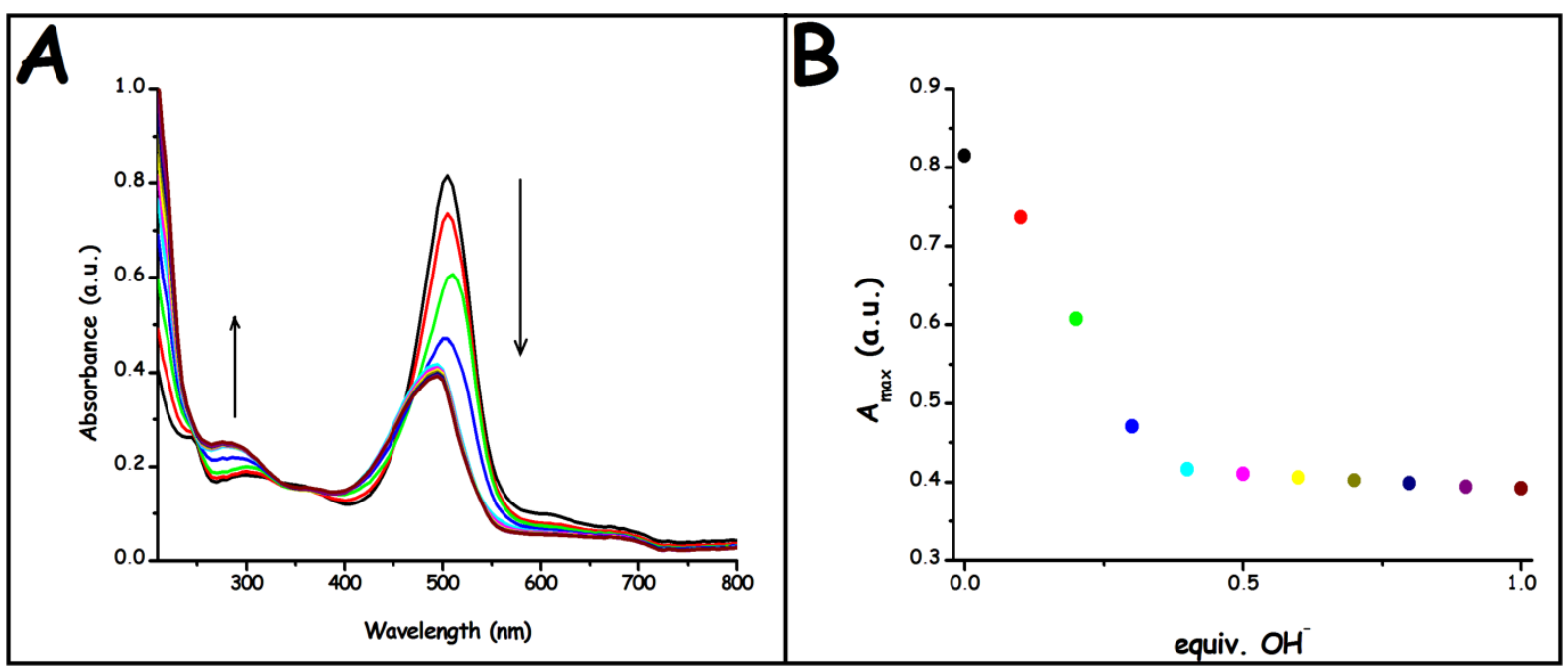

Figure S16. (a) Absorption spectra, (b) the curve of the absorption intensity changes of 1-Zn(33 $\mu \mathrm{M})$ upon addition of various amounts $(0,0.1,0.2,0.3,0.4,0.5,0.6,0.7,0.8,0.9$ and 1.0 equiv. $)$ of $\mathrm{OH}^{-}$.
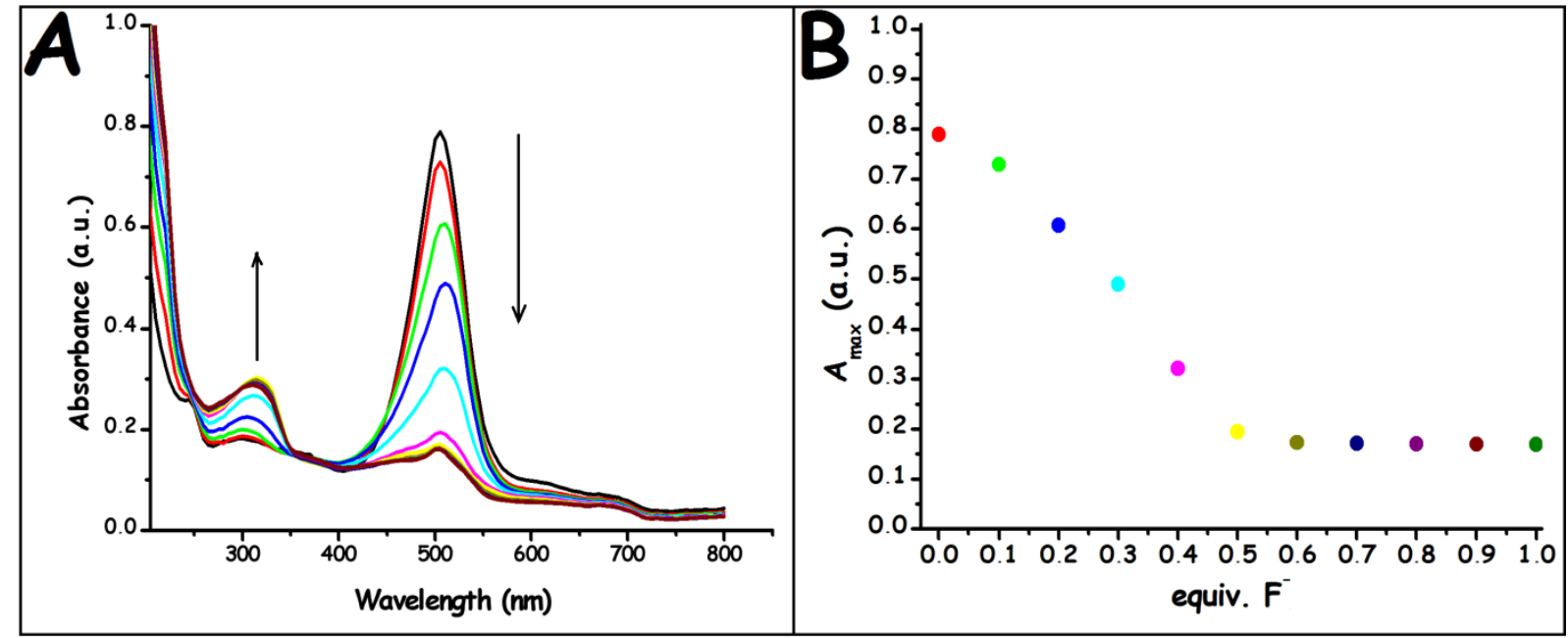

Figure S17. (a) Absorption spectra,(b) the curve of the absorption intensity changes of 1-Zn( $33 \mu \mathrm{M})$ upon addition of various concentrations $(0,0.1,0.2,0.3,0.4,0.5,0.6,0.7,0.8,0.9$ and 1.0 equiv. $)$ of $\mathrm{F}^{\text {- }}$. 

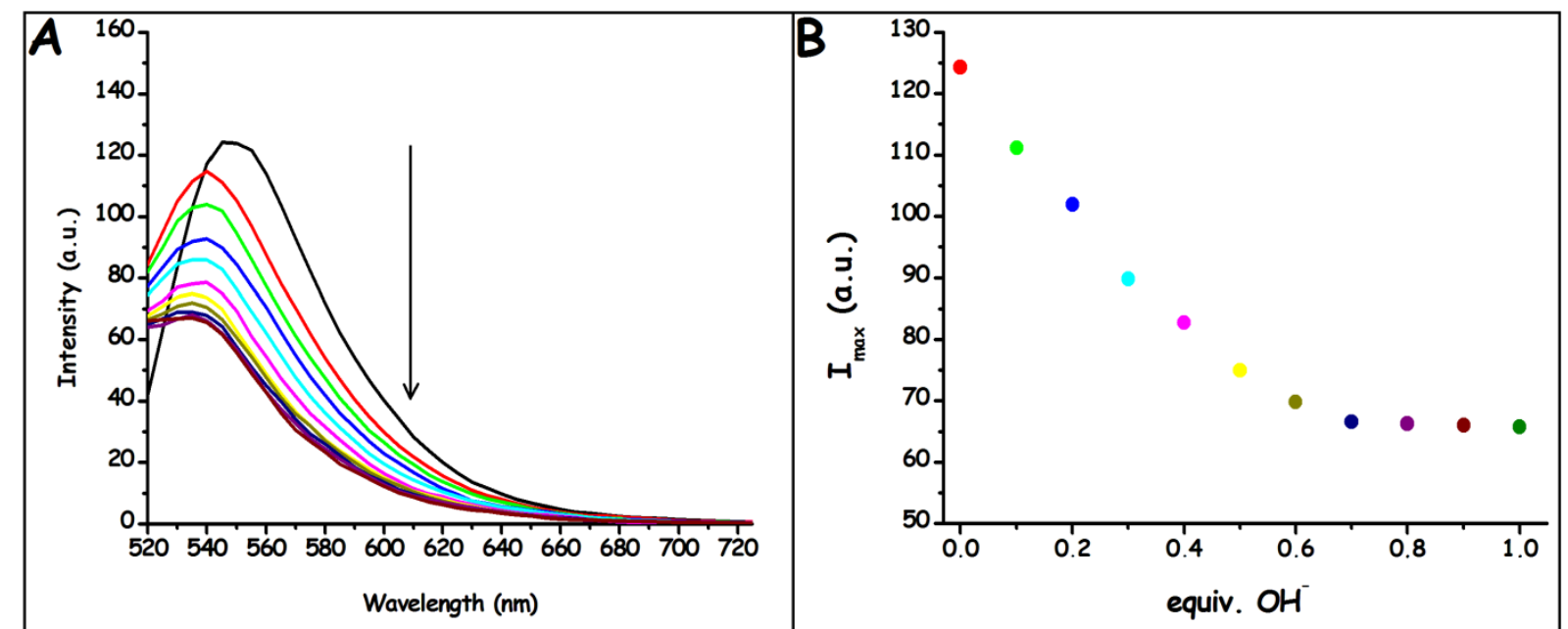

Figure S18.(a)Fluorescence spectra and, (b)the emission intensity changes for $1-\operatorname{Zn}(30 \mu \mathrm{M})$ upon addition of various amounts $(0,0.1,0.2,0.3,0.4,0.5,0.6,0.7,0.8,0.9$ and 1.0 equiv. $)$ of $\mathrm{OH}^{-i n} \mathrm{CH}_{3} \mathrm{CN}\left(\lambda_{\text {exc }}=500 \mathrm{~nm}\right)$.
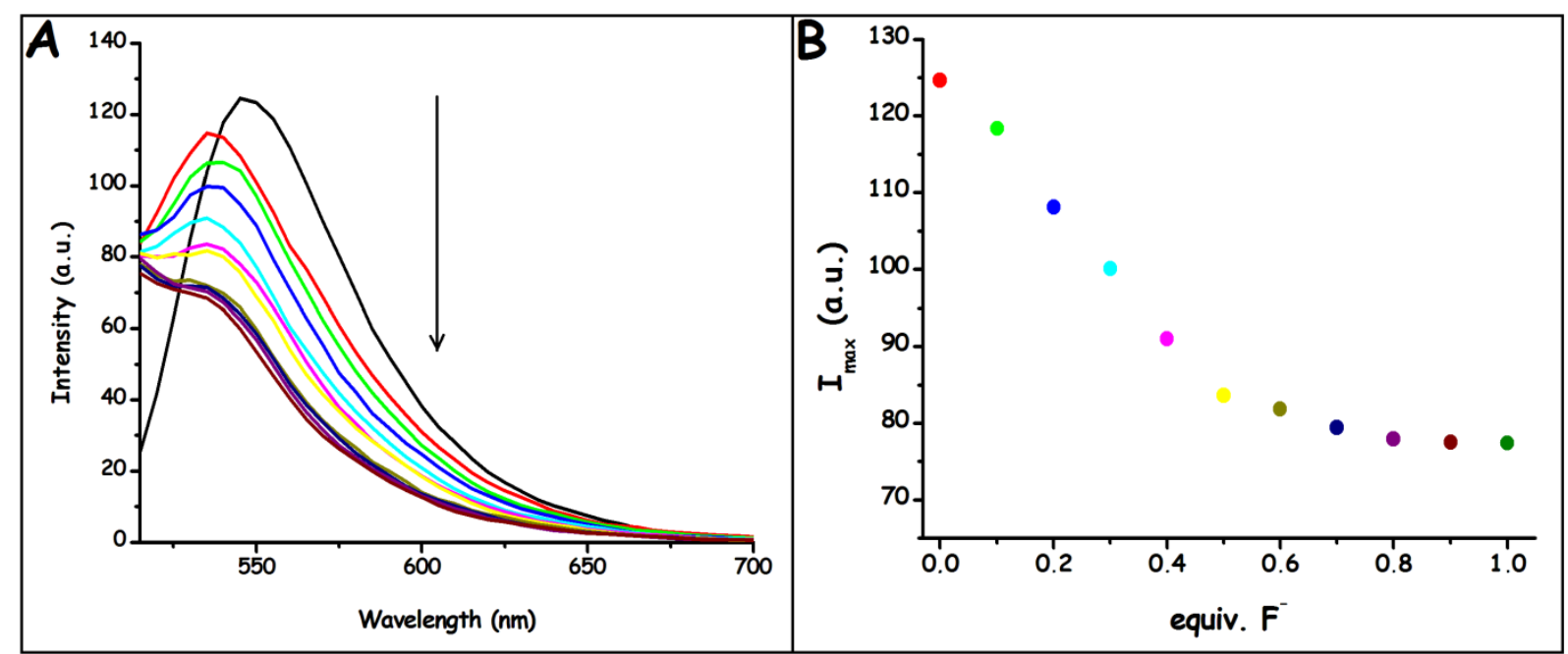

Figure S19.(a)Fluorescence spectra and, (b)the emission intensity changes for 1-Zn( $30 \mu \mathrm{M})$ upon addition of various amounts $(0,0.1,0.2,0.3,0.4,0.5,0.6,0.7,0.8,0.9$ and 1.0 equiv. $)$ of $\mathrm{F}$-in $\mathrm{CH}_{3} \mathrm{CN}\left(\lambda_{\text {exc }}=500 \mathrm{~nm}\right)$. 


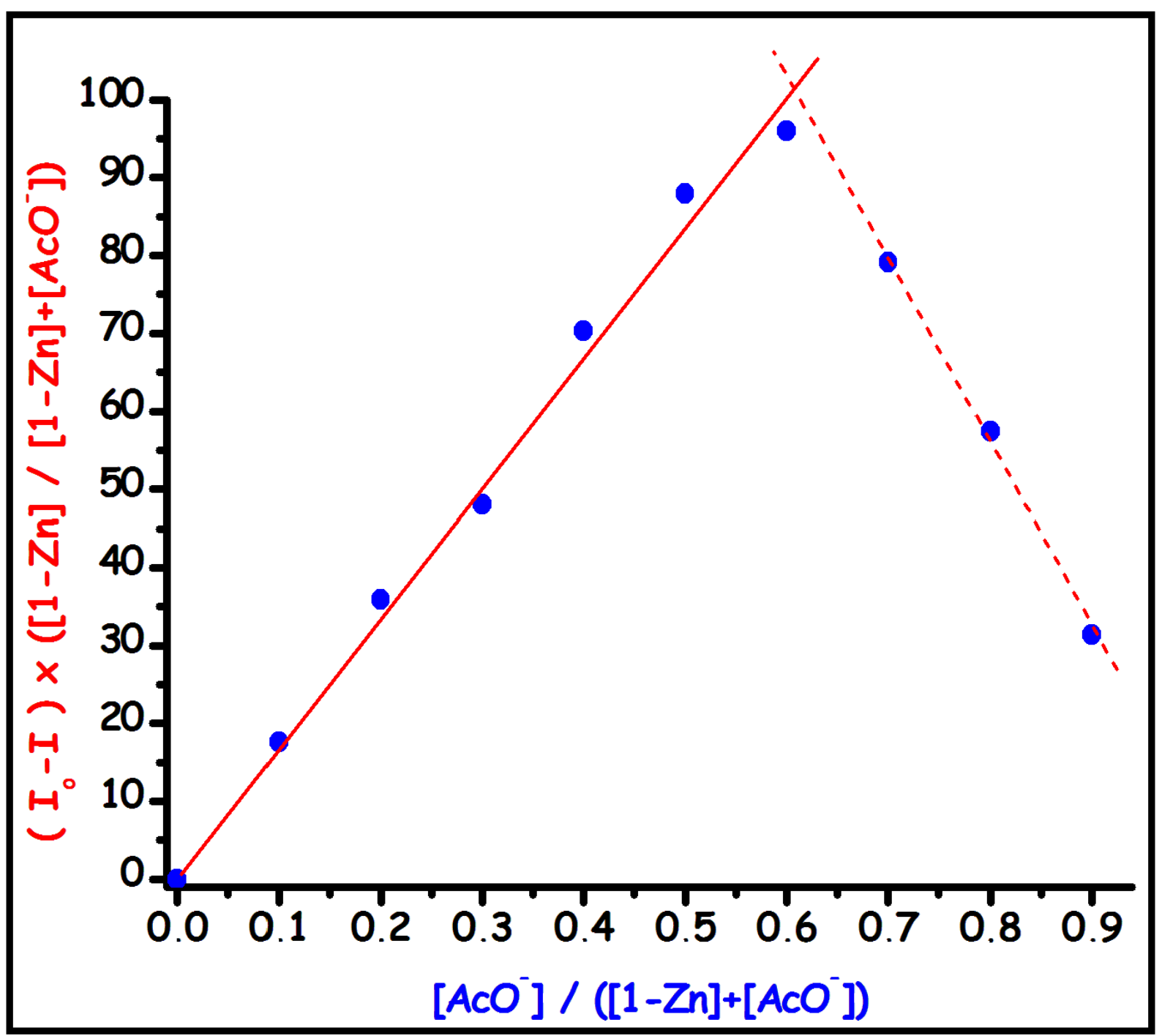

Figure S20. JOB plot diagram of 1-Zn for AcO- at a constant total concentration of $30 \mu \mathrm{M}$ of 1-Zn in $\mathrm{CH}_{3} \mathrm{CNat}^{-} 545 \mathrm{~nm}$. 
Fath ALGI*, Serkan KARAKAYA

Synthesis of Cycle BODIPY Dyad and Its Metal Complexes: Evaluation of Anion Recognition Features

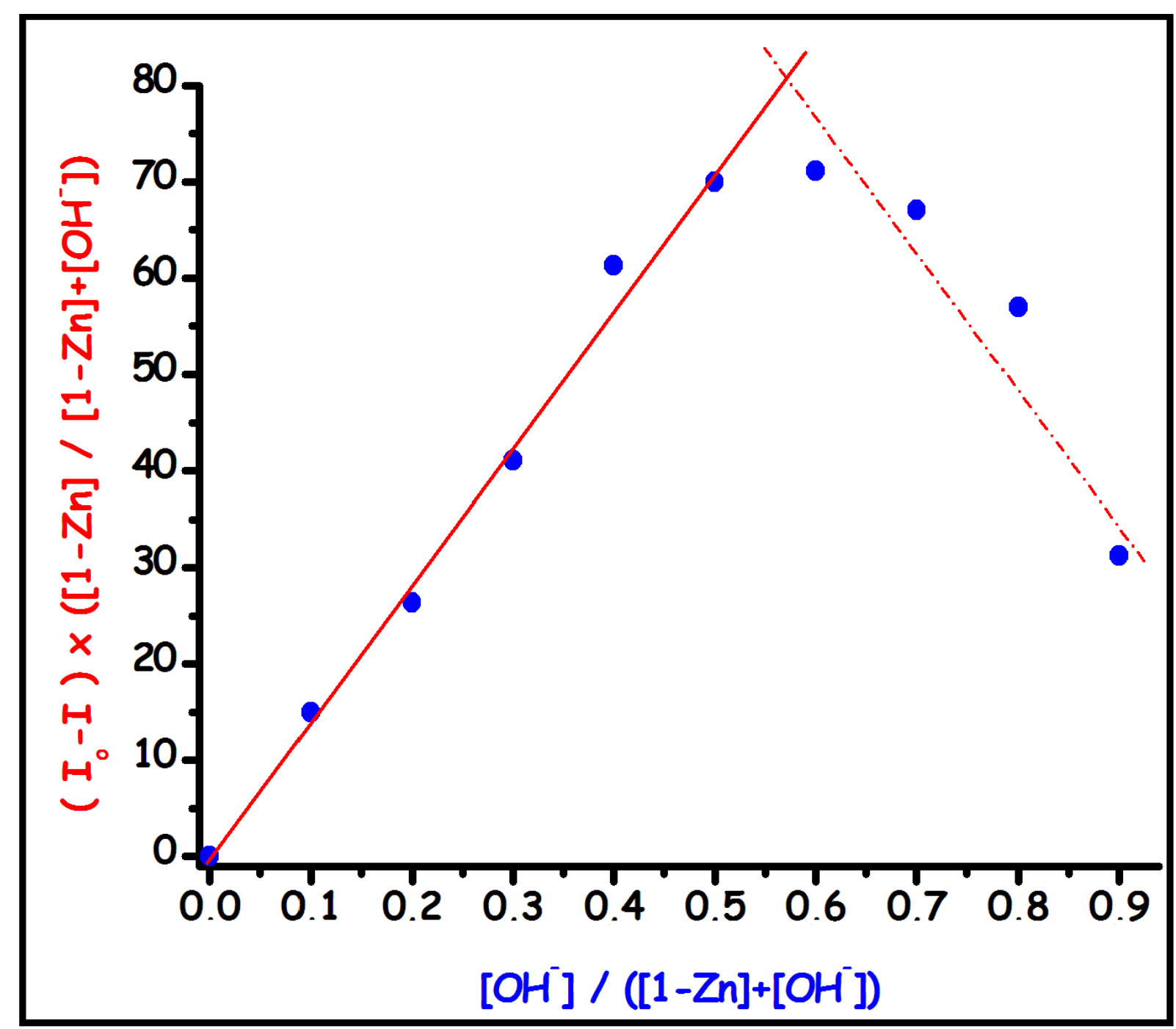

Figure S21. JOB plot diagram of 1-Zn for $\mathrm{OH}^{-}$at a constant total concentration of $30 \mu \mathrm{M}$ of 1-Zn in $\mathrm{CH}_{3} \mathrm{CNat}_{540} \mathrm{~nm}$.

96 


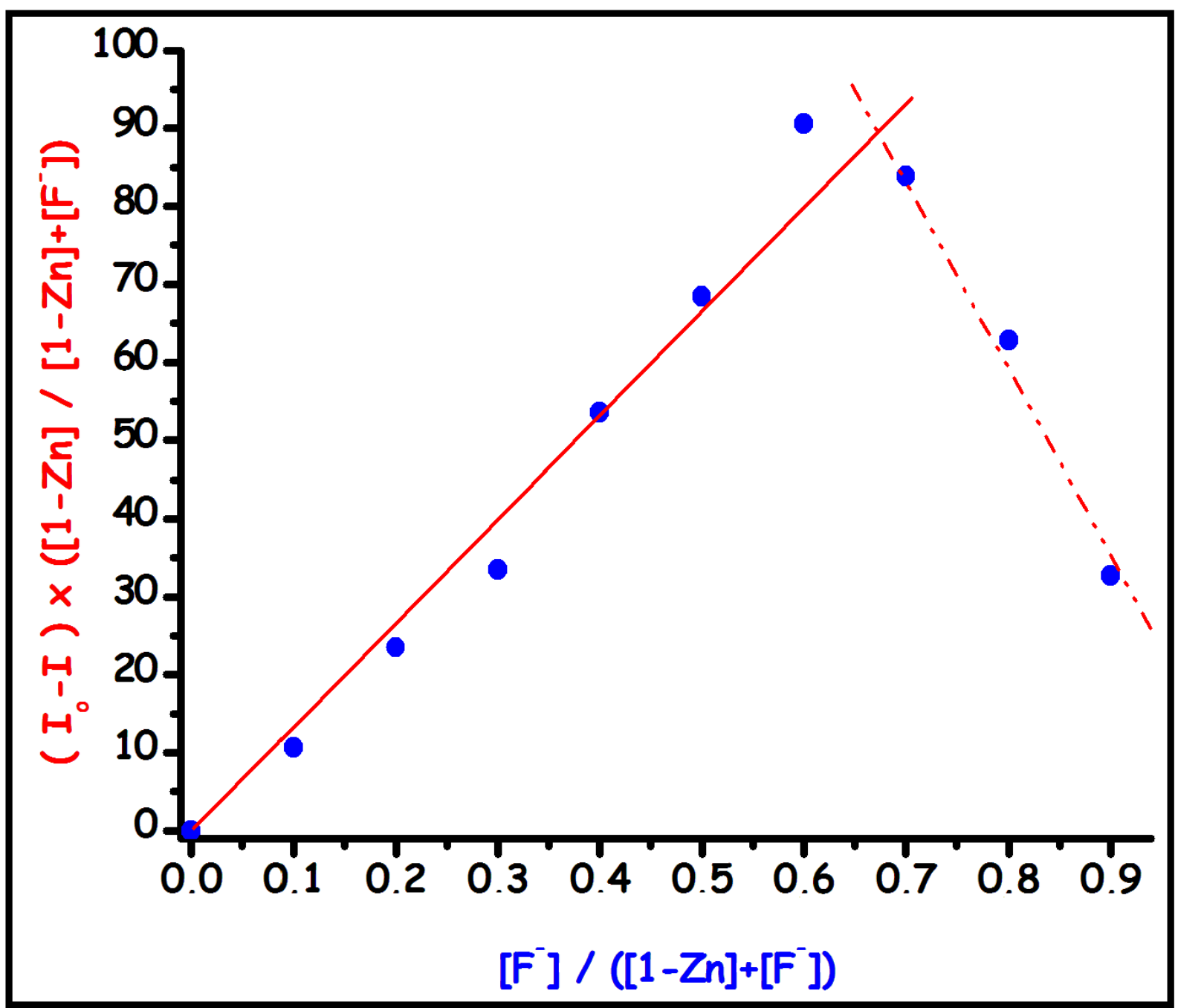

Figure S22. JOB plot diagram of 1-Zn for F- at a constant total concentration of $30 \mu \mathrm{M}$ of $\mathbf{1 - Z n}$ in $\mathrm{CH}_{3} \mathrm{CNat}_{540} \mathrm{~nm}$. 


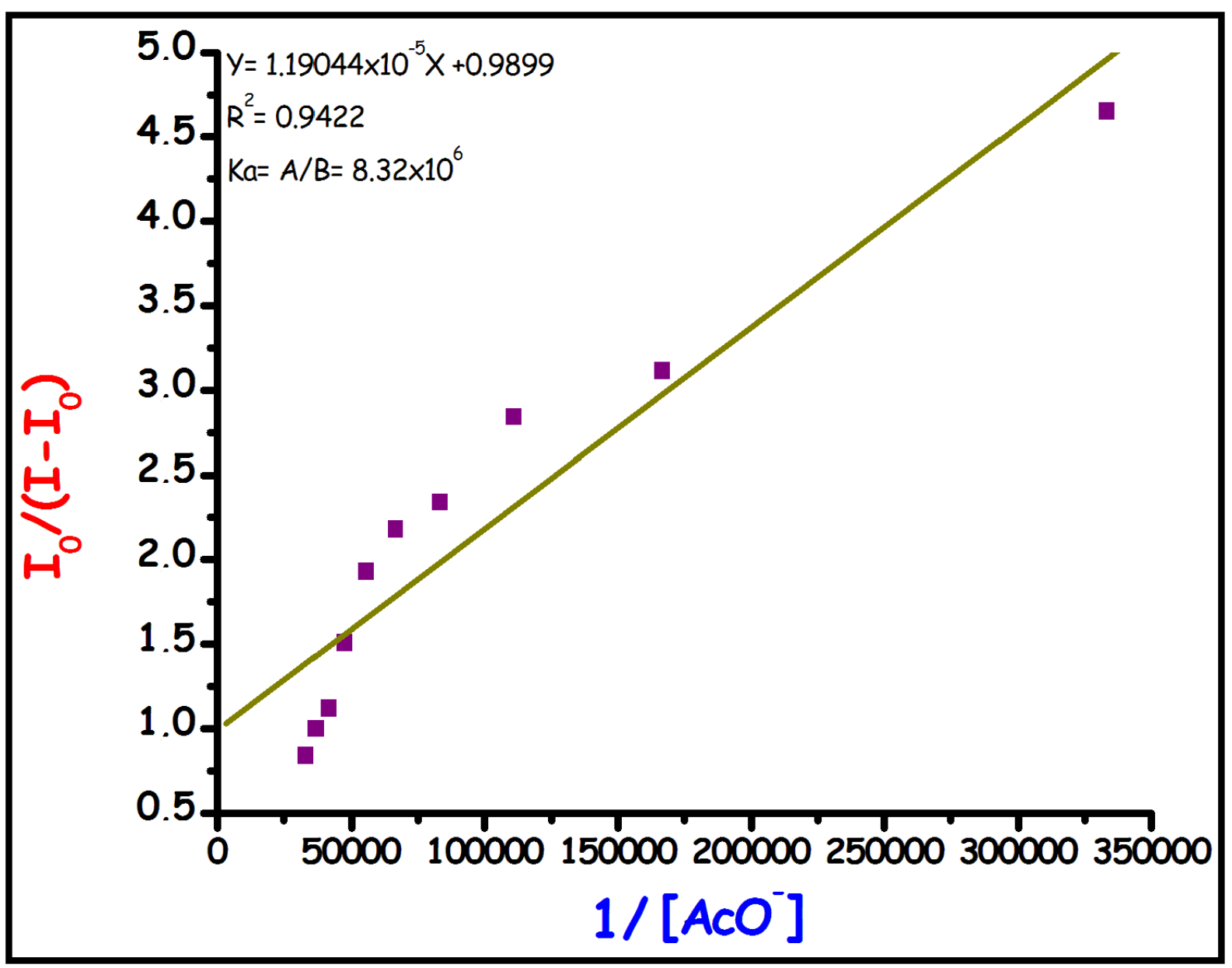

Figure S23. Linear regression curve 1-Zn for AcO- 


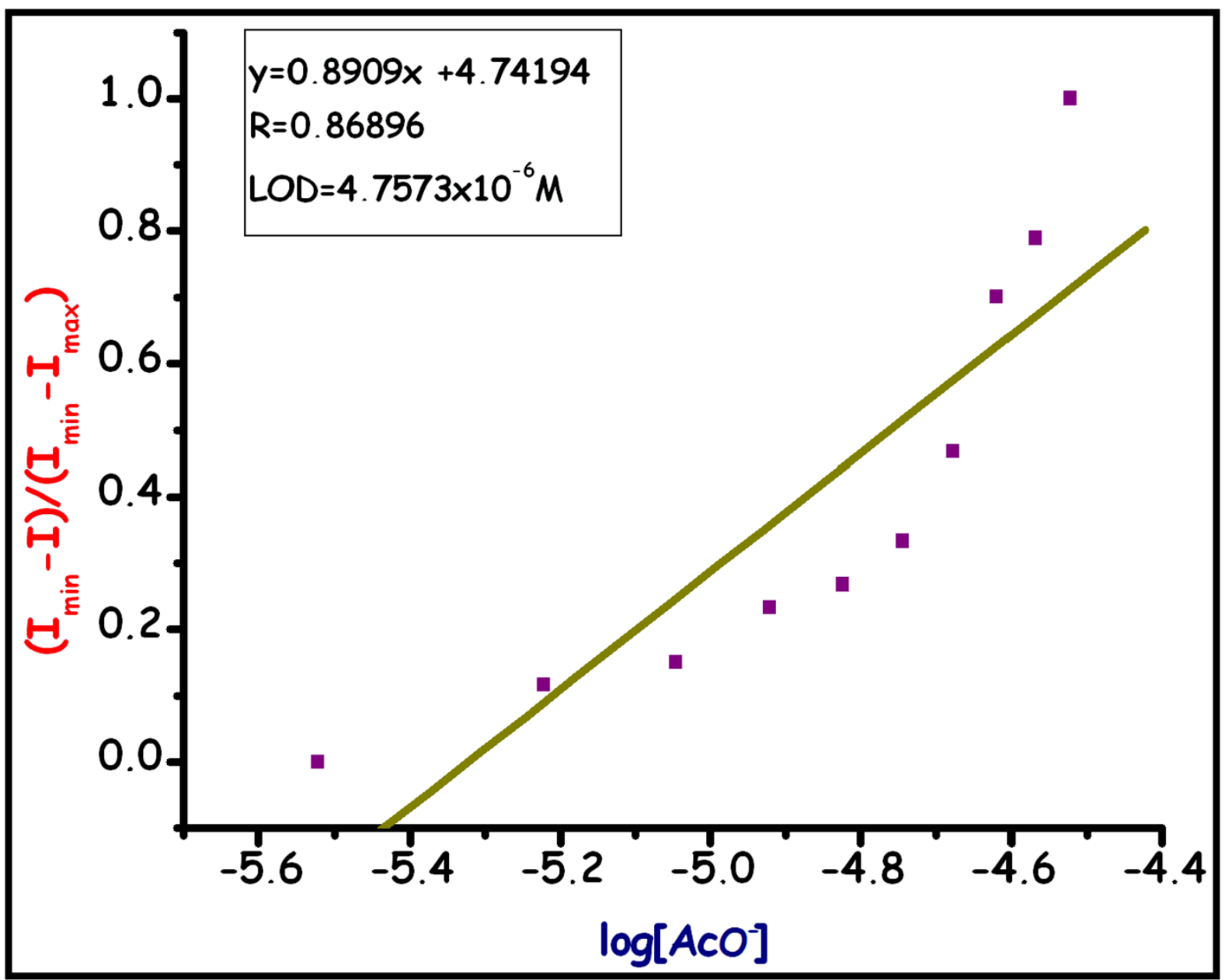

Figure S24. Plot of normalized fluorescence intensity of 1-Zn as a function of $\log [\mathrm{AcO}-]$ in $\mathrm{CH}_{3} \mathrm{CN}\left(\lambda_{\text {exc }}=500 \mathrm{~nm}\right.$ and $\left.\log \left[\mathrm{AcO}^{-}\right]=-5.323\right)$. 